WINTER, T.C. \& M.R. Carr, 1780

HYDROLOGIC SETTING OF WETLANDS IN THE

Sldu

COTTONWOOD LAKE AREA, STUTSMAN COUNTY,

NORTH DAKOTA

$x+2$

nis

U.S. GEOLOGICAL SURVEY

WATER RESOURCES INVESTIGATIONS 80-99

Prepared in cooperation with the U.S. Fish and Wildlife Service

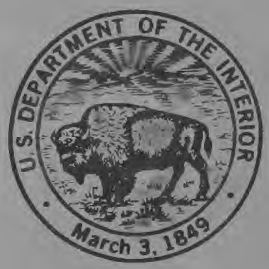




\begin{tabular}{|c|c|c|}
\hline $\begin{array}{l}\text { REPORT DOCUMENTATION } \\
\text { PAGE }\end{array}$ & 1. REPORT NO. & 3. Recipient's Accession No. \\
\hline \multirow{2}{*}{\multicolumn{2}{|c|}{$\begin{array}{l}\text { 4. Title and Subtitle } \\
\text { HYDROLOGIC SETTING OF WETLANDS IN THE COTTONWOOD LAKE AREA, } \\
\text { STUTSMAN COUNTY, NORTH DAKOTA }\end{array}$}} & $\begin{array}{l}\text { 5. Report Date } \\
\text { December } 1980\end{array}$ \\
\hline & & 6. \\
\hline \multirow{3}{*}{\multicolumn{2}{|c|}{$\begin{array}{l}\text { 7. Author(s) } \\
\text { Thomas C. Winter and Mark R. Carr } \\
\text { U. Performing Organization Name and Address } \\
\text { Box } 25046 \text {, Mail Stop 406, Denver Federal Center } \\
\text { Lakewood, CO } 80225\end{array}$}} & $\begin{array}{l}\text { 8. Performing Organization Rept. No. } \\
\text { USGS/WRI } 80-99\end{array}$ \\
\hline & & 10. Project/Task/Work Unit No. \\
\hline & & $\begin{array}{l}\text { 11. Contract(C) or Grant(G) No. } \\
\text { (C) } \\
\text { (G) }\end{array}$ \\
\hline \multicolumn{2}{|c|}{$\begin{array}{l}\text { 12. Sponsoring Organization Name and Address } \\
\text { U.S. Geological Survey, Water Resources Division } \\
\text { Box 25046, Mail Stop 406, Denver Federal Center } \\
\text { Lakewood, Co } 80225\end{array}$} & $\begin{array}{l}\text { 13. Type of Report \& Period Covered } \\
\text { Progress } \\
\text { 14. }\end{array}$ \\
\hline
\end{tabular}

15. Supplementary Notes

16. Abstract (Limit: 200 words) Because of growing interest in the role of lakes and wetlands in the hydrology of the praixie environment, a group of wetlands in the Cottonwood Lake area, Stutsman County, are being instrumented for long-term hydrologic studies. The study site is on a regional topographic high near the eastern edge of the Missouri Coteau and is underlain by more than 400 feet of glacial drift, largely clayey, silty till. Long-term climatic data indicate the study area is in a water deficient area--mean annual evaporation exceeds mean annual precipitation by about 18 inches.

Different methods are being used for comparison of measurements and estimates of each hydrologic component interacting with the lakes and wetlands. For example, for 3 months during 1979, estimates of precipitation for the study site using data collected at National Weather Service stations differed from that measured by a recording gage at the study site by several tenths of an inch for 14-day totals and differed by more than 0.5 inch for individual storms.

Numerical-simulation analysis of regional ground-water flow systems show the study site is situated in a regional recharge area, but local ground-water flow systems can discharge to lakes and wetlands within the recharge area. Instrumentation at the study site shows a complex interrelationship of wetlands and ground water. Based on data for 1979 only, some wetlands appear to recharge ground water, some are flow-through types and some are discharge points for ground water. These interrelationships vary throughout the year.

17. Document Analysis a. Descriptors Freshwater wetlands, lakes, surface-ground water relationships, water table, ground-water movement, seepage, lake beds, evaporation pans, mass-transfer evaporation

b. Identifiers/Open-Ended Terms

Relationship of ground water to wetlands, ground-water flow system analysis, ground-water flow models, prairie potholes

c. COSATI Field/Group

18. Availability Statement

No restriction on distribution

\begin{tabular}{l} 
19. Security Class (This Report) \\
UNCLASSIFIED \\
$\begin{array}{l}\text { 20. Security Class (This Page) } \\
\text { UNCLASSIFIED }\end{array}$ \\
\hline
\end{tabular}

See Instructions on Reverse
21. No. of Pages 42

22. Price

OPTIONAL FORM 272 (4-77) (Formerly NTIS-35) Department of Commerce 
HYDROLOGIC SETTING OF WETLANDS IN THE COTTONWOOD LAKE AREA, STUTSMAN COUNTY, NORTH DAKOTA

By Thomas C. Winter and Mark R. Carr

\section{U.S. GEOLOGICAL SURVEY}

Water-Resources Investigations 80-99

Prepared in cooperation with the U.S. Fish and Wildlife Service 


\section{UNITED STATES DEPARTMENT OF THE INTERIOR}

CECIL D. ANDRUS, Secretary

GEOLOGICAL SURVEY

H. William Menard, Director

For additional information write to:

Regional Hydrologist

Water Resources Division, Central Region

U.S. Geological Survey

Box 25046, Mail Stop 406

Denver Federal Center

Lakewood, Colorado 80225 


\section{CONTENTS}

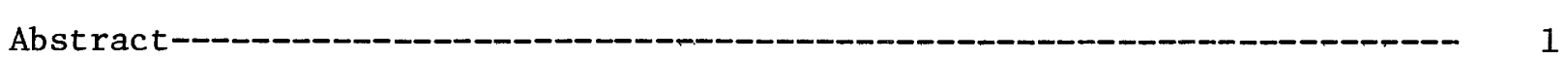

Introduction- 2

Background-_- 2

Purpose and scope-_- 3

Acknowledgments-_- 3

Environmental setting-

Location-- 3

Regional physiographic setting-_- 3

Climate--_- 5

Soils and vegetation-_- 10

Hydrology-_- 10

Instrumentation- 10

Atmospheric water-_- 10

Surface water-_- 11

Ground water-_-_- 11

Preliminary analysis- 17

Atmospheric water-- 17

Precipitation--_-_- 17

Evaporation--_- 21

Surface water-_-_- 24

Ground water--_- 24

Regional ground-water flow-_- 24

Local ground-water flow and interaction with wetlands

at study site-- 33

Future study needs-- 39

Short term- 39

Long term- 39

References-_- 40 


\section{ILLUSTRATIONS}

Page

Figure 1. Map showing glacial geology of North Dakota and location of study site in the Cottonwood Lake area, Stutsman County------ 4

2. Map showing bedrock geology of North Dakota--_-_-_-_-_--- 6

3. Map showing regional topographic setting of the Cottonwood Lake area study site and its relationship to nearby major topographic features of the Missouri Coteau--_-_-_-_-_----- 8

4. Lithologic section of glacial deposits in the general region

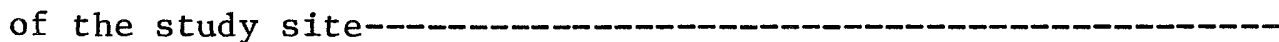

5. Map showing location of hydrologic instrumentation at the study site-- 12

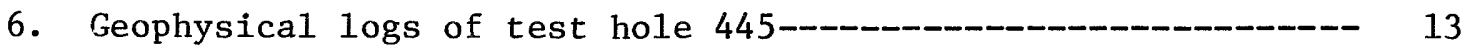

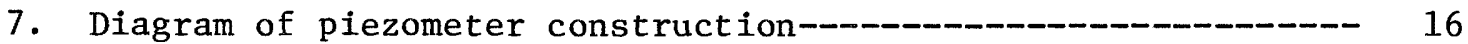

8. Graphs showing precipitation at the study site and at the four nearest National Weather Service stations, mid-Ju1y to mid-October 1979-_-_-_-

9. Precipitation maps and comparison of three regionalization techniques to estimate precipitation at the study site from National Weather Service data, July 11-24, 1979.
(A) 14-day total precipitation.
(B) Largest storm

during the 14-day period-_-_-_-_-_-

10. Graphs showing difference between precipitation as measured by the recording gage at the study site and that estimated by three regionalization techniques using National Weather Service data, mid-July to mid-October 1979 . (A) Tota1 precipitation for each 14-day period. (B) Largest storm during each 14-day period-_-_-_-_-_

11. Graphs showing wind speed, relative humidity, air temperature, and water temperature at wetland P1-_-_-_-_---

12. Hydrographs of water levels in selected wetlands at the study site-- 
13. Hydrographs of water levels in wells and piezometers at the study site

14. Hydrologic sections showing ground-water movement in the general region of the Missouri Coteau associated with the study site, based on published data-_-

15. Hydrologic sections showing numerical simulations of ground-water movement in the general region of the Missouri Coteau associated with the study site-

16. Water-table maps of part of the study site. (A) May 31 ,

1979. (B) August 23, 1979-_

17 Hydrologic sections of the study site showing relationships of wetland levels to water-table levels for six dates during 1979-

\section{TABLES}

Table 1. Description and 1ithologic logs of shallow, augered wells----

2. Completion depths and land-surface altitudes of piezometers on the west side of wetland P1 and lithologic $10 \mathrm{~g}$ of test hole 445-C-C-C

3. Comparison of two mass-transfer methods and one pan method for estimating evaporation from wetland $\mathrm{P} 1$, mid-July to mid-October, 1979 


\section{CONVERSION FACTORS}

For the convenience of those readers who prefer to use International System (metric) units rather than inch-pound units, the conversion factors for terms used in this report are listed below:

Mu1tiply

inch-pound unit

By

To obtain metric unit

inch (in)

25.40

millimeter (mm)

foot ( $f t$ )

0.3048

meter (m)

mile (mi)

1.609

kilometer $(\mathrm{km})$

foot per day ( $f t / d$ )

0.3048

meter per day $(\mathrm{m} / \mathrm{d})$

pounds (1bs)

0.454

kilogram (kg)

National Geodetic Vertical Datum of 1929 (NGVD of 1929).--A geodetic datum derived from a general adjustment of the first-order level nets of both the United States and Canada, formerly called "mean sea level". The datum was derived from the average sea level over a period of many years at 26 tide stations along the Atlantic, Gulf of Mexico, and Pacific coasts.

Brand names used in this report are for identification on1y and do not imp1y endorsement by the U.S. Geological Survey. 


\title{
HYDROLOGIC SETTING OF WETLANDS IN THE COTTONWOOD LAKE AREA, STUTSMAN COUNTY, NORTH DAKOTA
}

\author{
By Thomas C. Winter and Mark R. Carr
}

\begin{abstract}
Because of growing interest in the role of lakes and wetlands in the hydrology of the prairie environment, a group of wetlands in the Cottonwood Lake area, Stutsman County, are being instrumented for long-term hydrologic studies. The study site is on a regional topographic high near the eastern edge of the Missouri Coteau and is underlain by more than 400 feet of glacial drift, largely clayey, silty till. Long-term climatic data indicate the study area is in a water deficient area--mean annual evaporation exceeds mean annual precipitation by about 18 inches.

Different methods are being used for comparison of measurements and estimates of each hydrologic component interacting with the lakes and wetlands. For example, for 3 months during 1979, estimates of precipitation for the study site using data collected at National Weather Service stations differed from that measured by a recording gage at the study site by several tenths of an inch for 14-day totals and differed by more than 0.5 inch for individual storms.
\end{abstract}

Numerical-simulation analysis of regional ground-water flow systems show the study site is situated in a regional recharge area, but local groundwater flow systems can discharge to lakes and wetlands within the recharge area. Instrumentation at the study site shows a complex interrelationship of wetlands and ground water. Based on data for 1979 on 1 y, some wetlands appear to recharge ground water, some wetlands are flow-through types where ground water enters one side and surface water seeps into the ground on the other side, and some wetlands are discharge points for ground water. Further, these interrelationships vary throughout the year. 


\section{INTRODUCTION}

\section{Background}

The role wetlands have in the hydrologic system of the prairie environment has been a subject of considerable interest for many years. The interest in prairie wetlands, commonly called prairie potholes, stems from a wide range of scientific, environmental, and economic considerations.

The prairie wetlands, including those in Canada, are one of the principal breeding grounds for waterfow1 in North America. The wetlands also are recognized as a rich soil resource for agricultural production if they are drained. In addition, prairie wetlands have long been of interest to hydrologists because they are believed to have a role in flood control and in ground-water recharge and discharge. Because of these sometimesconflicting interests, the hydrologic function of prairie wetlands has been a subject of considerable controversy for many years.

A few studies of the hydrology of prairie lakes and wetlands have been done in North Dakota (Eisenlohr and others, 1972; Sloan, 1972; Downing and Paterka, 1978); South Dakota (Barari, 1971a, 1971b); and Canada (Meyboom, 1966, 1967, Lissey, 1971). The studies are valuable because they began to explain the role of prairie lakes and wetlands in the hydrologic system. Although many questions were answered, many remained unsolved and new questions arose. The hydrology of the prairie wetlands remains one of the least-studied hydrologic features of the prairie landscape. Much controversy remains concerning the hydrologic function of prairie wetlands and the effects on the wetlands of man-related activities such as ground-water development, pipeline construction, and agricultural practices. More intensive study of the hydrology of prairie lakes and wetlands is needed for proper and effective management of the water and related land resources of the prairie environment.

The need for renewed hydrologic studies of prairie wetlands in the United States has been recognized by a number of Governmental agencies. The U.S. Geological Survey, for example, has identified these water bodies as one of the eight highest-priority lake environments in the United States for establishment of cooperative lake hydrology research studies. The U.S. Fish and Wildlife Service also has an intense interest in the hydrology of the prairie wetlands because of their importance as habitat for waterfowl. The mutual interest of these two agencies led to a cooperative agreement for research on the hydrology and related chemistry and biology of prairie wetlands.

The 1ong-term goal of these studies is to develop an understanding of the basic principles underlying the interaction of the wetlands with atmospheric water, surface water, and ground water. The interaction of wetlands with ground water will be emphasized because it is the least-understood component of the hydrologic system interacting with lakes and wetlands. An 
integral part of the studies will involve comparative analyses of various methods and analytical techniques with respect to their cost, personnel requirements, and errors inherent in each method.

Because the information on hydrologic fluxes will be available, the studies lend themselves to, and will include, associated studies of nutrient and other chemical fluxes to and from the wetlands. These in turn will be related to studies of the hydrological, chemical, and biological processes within the lakes and wetlands themselves.

\section{Purpose And Scope}

The purpose of this progress report is to: (1) Describe the physiographic and climatic setting of a group of wetlands near the Cottonwood Lake area, Stutsman County, North Dakota, (2) describe the project design, instrumentation, and field work accomplished during the first $1 \frac{1}{2}$ years of activity, and (3) provide an example of the study approach by analyzing the data collected through October 1979.

\section{Acknowledgments}

Permission to work on U.S. Fish and Wildlife Service property is gratefully acknowledged. The on-site assistance provided by personnel of the U.S. Fish and Wildlife Service's Northern Prairie Wildlife Research Center, sometimes under adverse climatic conditions, is sincerely appreciated. The continuing and enthusiastic support of George Swanson of the Northern Prairie Wildlife Research Center is invaluable.

\section{ENVIRONMENTAL SETTING}

\section{Location}

The study site is located about 28 road miles northwest of Jamestown, Stutsman County, North Dakota (fig. 1), in the SW $\frac{1}{4}$ of section 19, T. 142 N., R. $66 \mathrm{~W}$. and the SE $\frac{1}{4}$ of section 24, T. $142 \mathrm{~N}$., R. $67 \mathrm{~W}$. The site is in the Goldwin SE quadrangle map area ( $7 \frac{1}{2}-$ minute series) of the U.S. Geological Survey.

\section{Regional Physiographic Setting}

The study site is near the eastern edge of the Missouri Coteau, a large glacial drift complex consisting of end moraine, stagnation moraine, icecontact, and outwash deposits (Colton and others, 1963), (fig. 1). In North Dakota the thickness of this drift complex locally is greater than 500 feet (Bluemle, 1971). In much of northwestern Stutsman County, including the Cottonwood Lake area, the drift thickness is greater than 400 feet. 


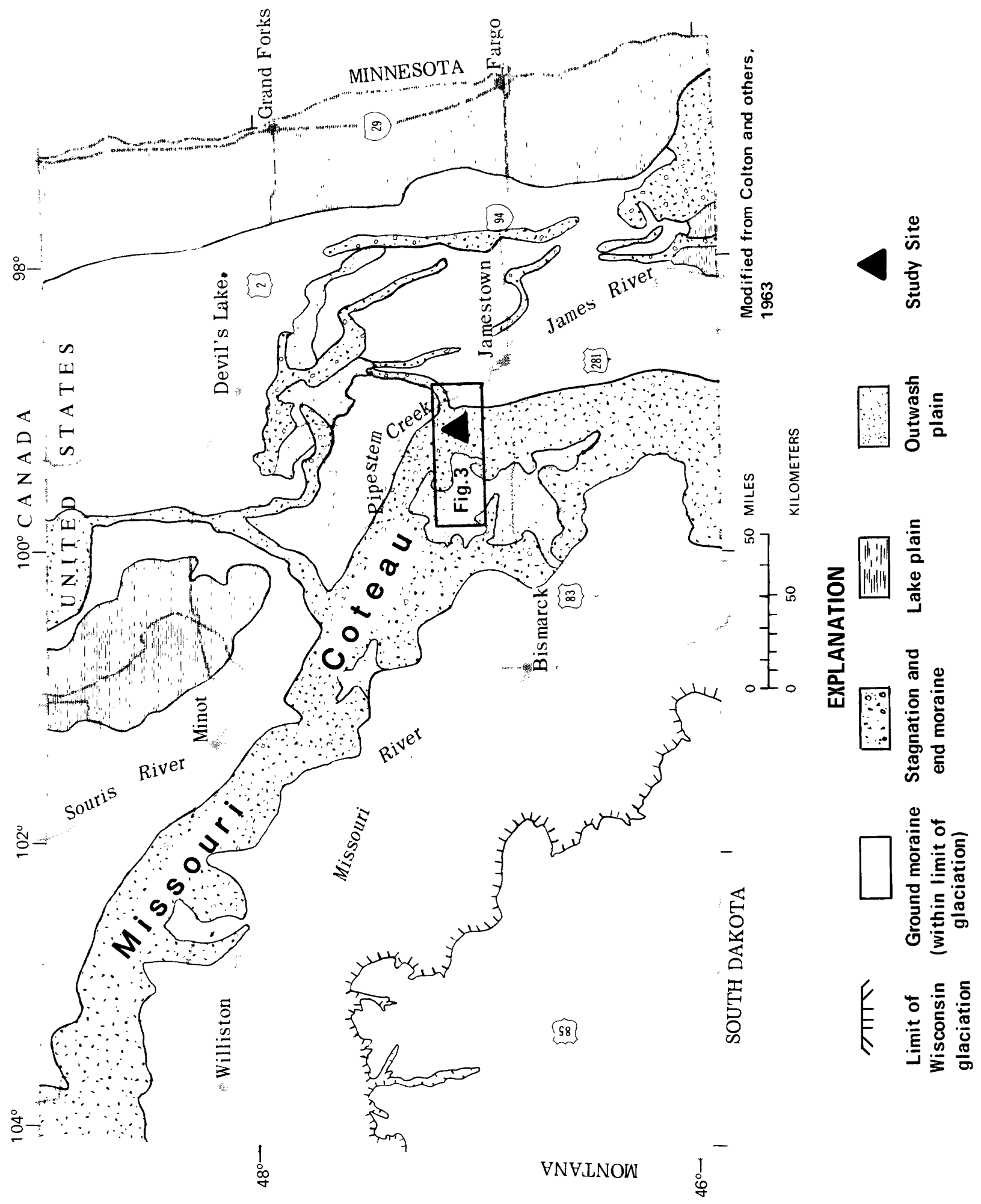

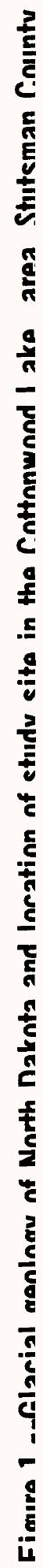


Much of the drift comprising the Missouri Coteau in the study area consists of clayey, silty till. The clay content of the till was derived from the large area of the Pierre Formation in eastern North Dakota (fig. 2).

More detailed physiographic characteristics of the Missouri Coteau in the vicinity of the study site are shown in figures 3 and 4 . The more massive part of the Missouri Coteau to the west of the study site genera11y has land-surface altitudes higher than 1,900 feet above the National Geodetic Vertical Datum (NGVD) of 1929. In the vicinity of Woodworth a few small topographic knobs have altitudes higher than 2,100 feet above the NGVD of 1929. The study site is on a small highland separated from the more massive part of the Missouri Coteau by a lowland that is less than 1,800 feet above the NGVD of 1929 in many places (fig. 3). This lower area contains a number of saline 1akes.

The types of drift deposits in the area of the Missouri Coteau shown in figure 3 are shown in figure 4. The section (fig. 4) was drawn from data published in reports on Stutsman County (Huxel and Petri, 1963) and Kidder County (Randich and others, 1962). The section shows the drift is predominately clayey, silty till, and a large number of silt, sand, and gravel lenses are included within the till. A large area of sand and gravel outwash occurs at the surface in the western part of the section. This low area of outwash also contains a number of saline lakes.

\section{Climate}

North Dakota has a continental climate generally characterized by warm summers and cold winters, and wide variations in extreme temperatures and precipitation. The following information is taken from Jensen (no date) and is based on the period of record from 1931-60. In the study area of northern Stutsman County the annual mean temperature is about $40^{\circ} \mathrm{F}$--the extreme mean monthly temperatures range from about $7^{\circ} \mathrm{F}$ during January to $70^{\circ} \mathrm{F}$ during July. The average annual number of days when the temperature is $32^{\circ} \mathrm{F}$ or colder is about 195, and the average annual number of days when the temperature is colder than $0^{\circ} \mathrm{F}$ is about 55. The mean length of the freeze-free period is about 120 days.

The mean annual precipitation in the study area is about 17.5 inches-the extreme mean monthly values range from about 0.4 inch during December to 3.4 inches during June. The mean April through September precipitation is 13.5 inches. Mean annual snowfall is about 34 inches. The mean date of the first 1 inch or more snow depth is about December 5, and the mean date of the last 1 inch snow cover is about March 23.

Mean annual lake evaporation during 1946-55 was estimated by Kohler and others (1959) to be about 36 inches. 

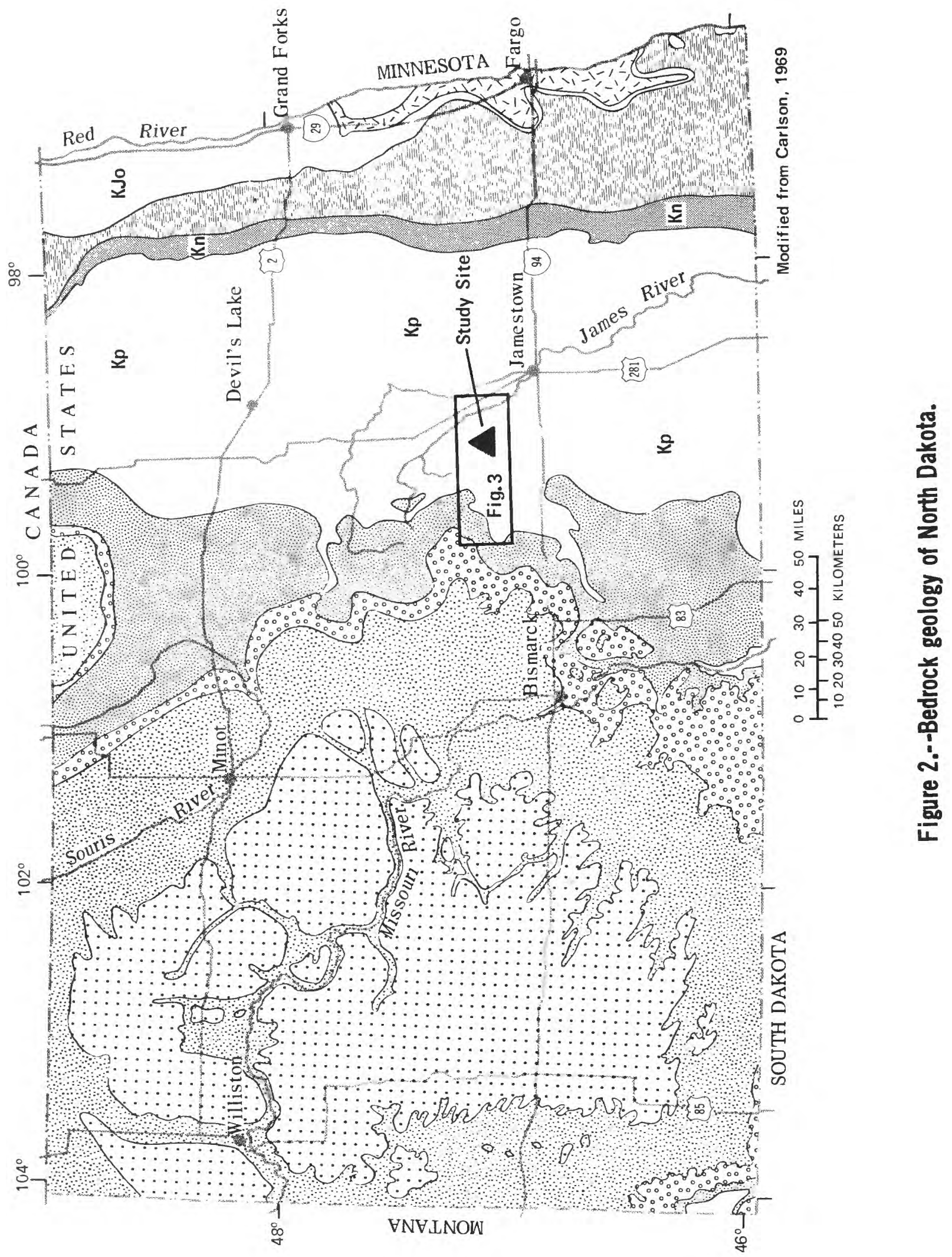


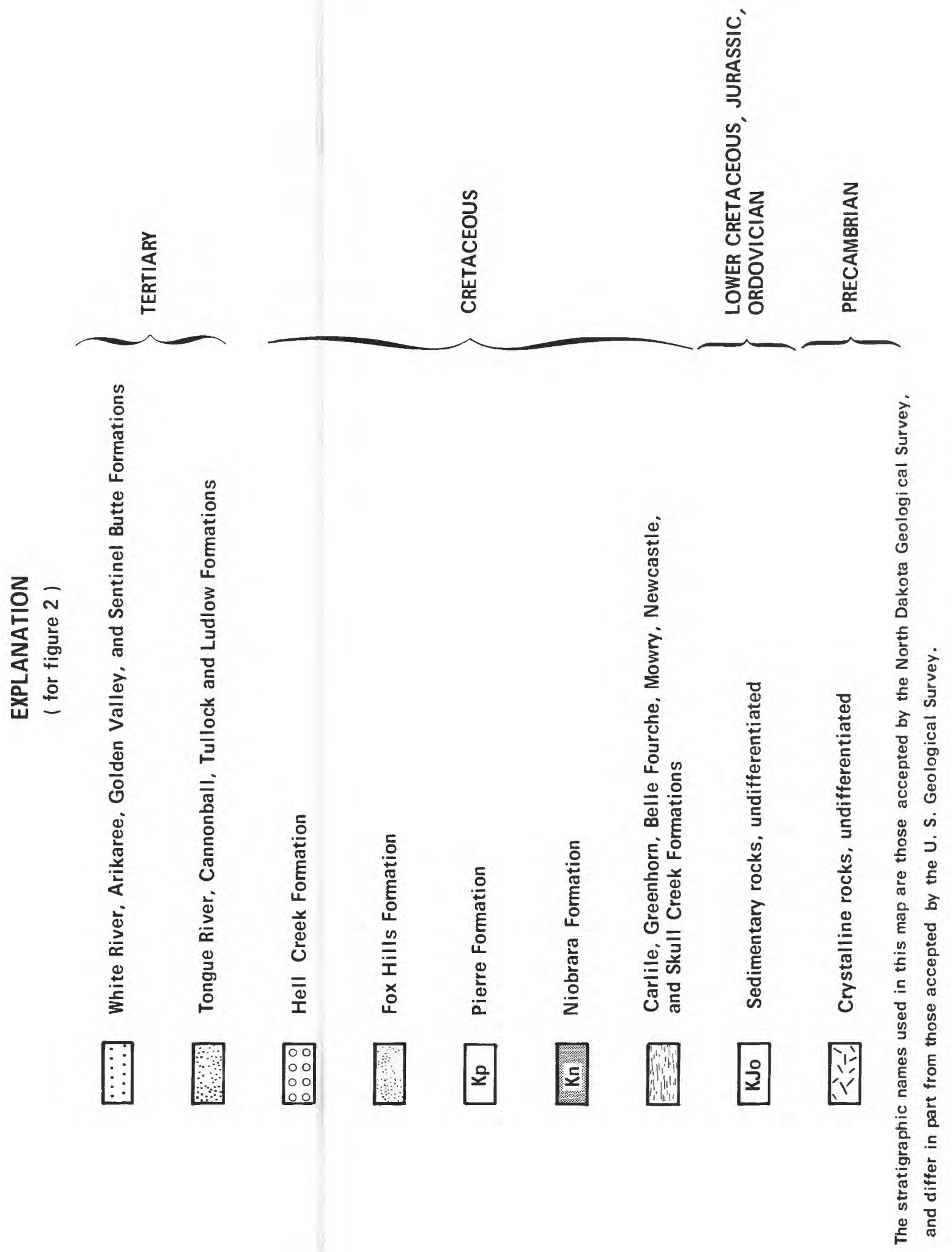




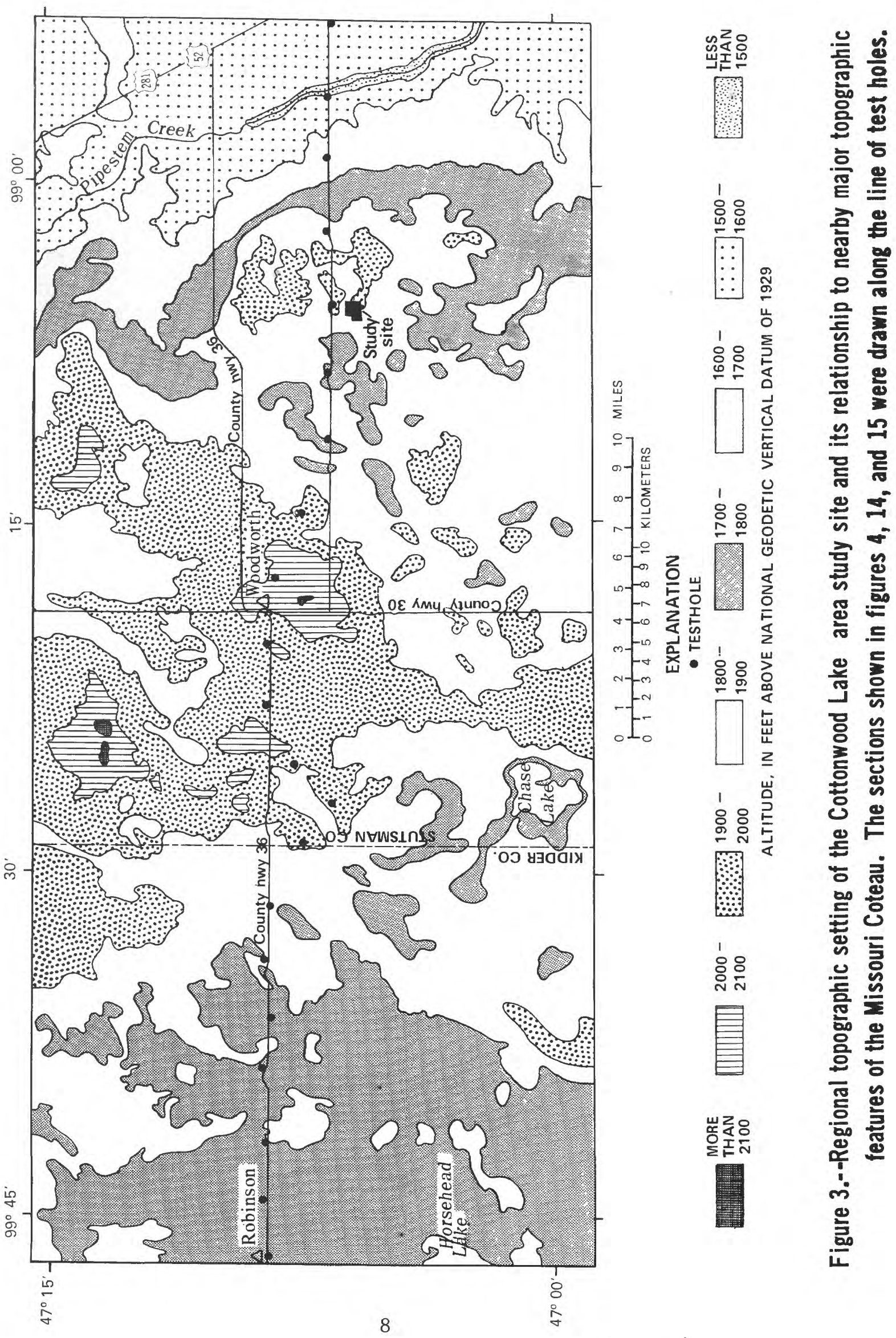




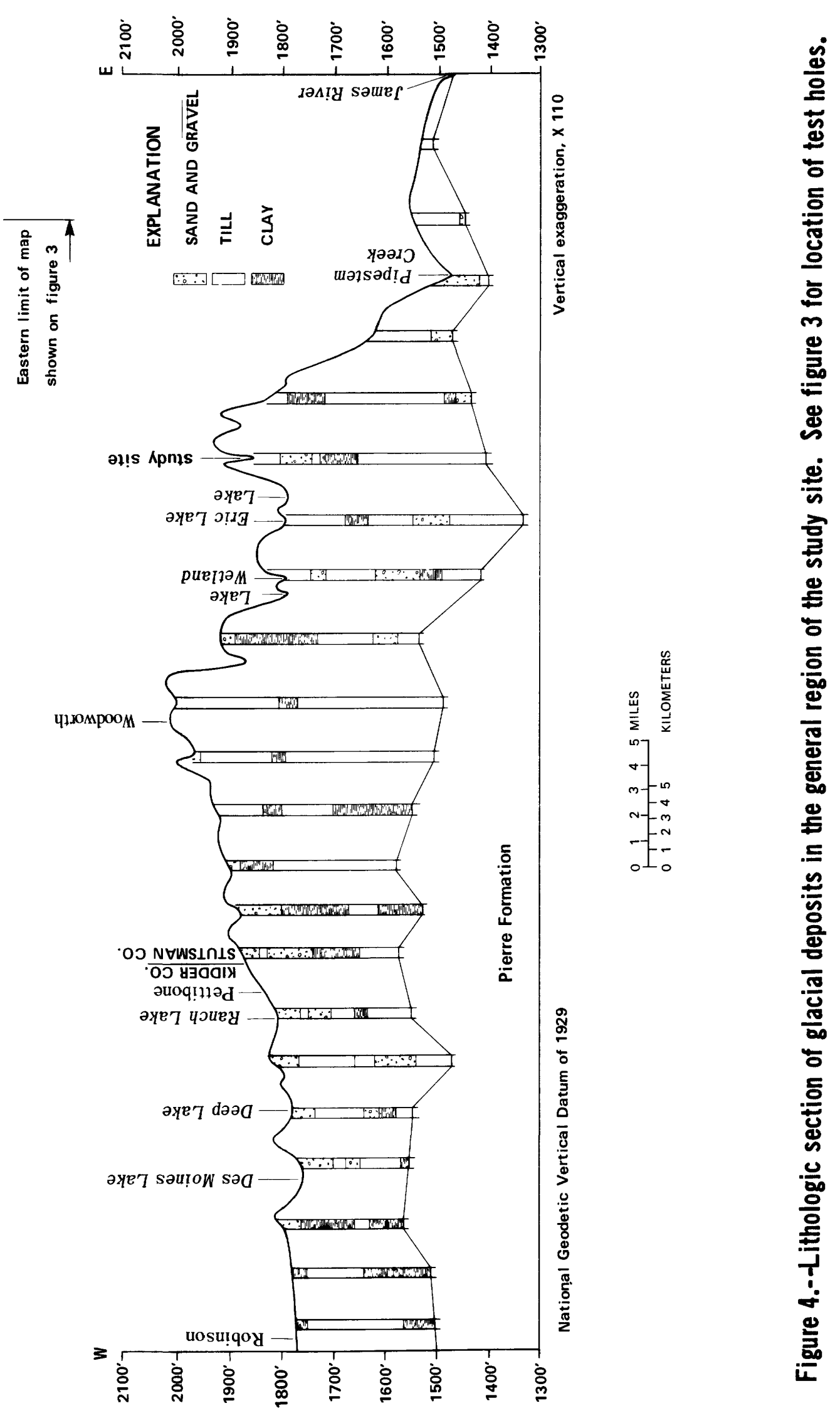




\section{Soils And Vegetation}

Soils in the study area were classified by Patterson and others (1968) as Barnes-Buse, rolling. They are soils that have a relatively thick black surface layer (Chernozem) and associated soils that have a relatively thin surface layer (Regoso1), very limy subsoil (calcium carbonate Solonchak), or claypan subsoil (Solonetz). As stated in their report "A typical Barnes-Buse soil area consists of moderately sloping, irregularly-shaped hills with small areas of more gentle slopes and swales and a few moderately steep knobs. Ponds, marshes, and areas of poorly-drained soils occur throughout the landscape. The soils are on loam to clay-loam glacial till. Barnes soils dominate the moderate and gentle slopes. . . Buse soils occupy strongly rounded hilltops and knobs. . . Svea soils are on concave lower slopes. . ." Parnell and Tetonka soils occupy the lowlands, are organic rich, and are subject to intermittent wetness and ponding.

Prairie vegetation consisting of a wide variety of herbs and grasses dominates the landscape. A few small patches of aspen and chokeberry nccur on north-facing slopes. A comprehensive report on vegetation of the wetlands is given by Stewart and Kantrud (1972).

\section{HYDROLOGY}

\section{Instrumentation}

Atmospheric Water

Instrumentation for measuring precipitation and for measuring evaporation by the mass-transfer method was installed July 11, 1979. The location of all instrumentation is shown in figure 5.

A Weathermeasure $\mathrm{P}-501-\mathrm{I}$ remote-recording rain gage and $\mathrm{P}-521$ event recorder are being used to measure precipitation. The P-501-I is a tippingbucket-type rain gage with an 8-inch orifice that is designed to tip after each 0.01 inch of rainfall. A Weathertronics 6310 standard nonrecording rain and snow gage was installed January 1980.

To calculate evaporation by the mass-transfer method, data are needed for air temperature, relative humidity, surface-water temperature, and windspeed. Air temperature and relative humidity are measured by a Belfort Hygrothermograph, air temperature is measured by thermocouple and relative humidity is measured by the contraction and expansion of human-hair elements. The water-temperature and windspeed instruments are located on a raft in the middle of pothole P1. The water temperature probe is positioned about 1 inch below the water surface and connected to a Marshalltown (Model 2200) recorder. Windspeed is recorded on a Belfort totalizing anemometer which was placed about 7 feet above the water surface. For every 10 miles per hour of wind passage recorded by the Belfort anemometer a tick is made on the edge of the water-temperature chart. The instrument charts are changed weekly; separate 
thermometers are used to check air and water temperatures and a psychrometer is used to check relative humidity.

\section{Surface Water}

Staff gages (fig. 5) were installed in some of the wetlands during the summer of 1978. Relative altitudes of all gages were determined by leveling except those in potholes $\mathrm{P} 2, \mathrm{P} 4$, and $\mathrm{T} 7$. The gages were read once a week during the ice-free period from April to October, 1979.

\section{Ground Water}

Twenty shallow wells and a nest of five deep piezometers were constructed at the study site (fig. 5). The shallow wells are used to define the water-table configuration, and the piezometer nest is used to determine the vertical hydraulic-head gradient within the ground-water system on the west side of wetland P1.

The shallow wells were drilled by auger during August 1978. The depth of test holes, depth of wells, altitude of land surface, and 1ithology penetrated are summarized in table 1. Because it is difficult to identify the water table immediately after drilling in the fine-textured clayey till, (there usually is no water in the test hole) the holes were drilled 5 to 10 feet below the change from oxidized (brown) to reduced (gray) till. Some of the augered holes were drilled primarily to determine stratigraphy. The sha11ow wells were constructed using $1 \frac{1}{4}$-inch plastic pipe and metal sand points with 2-foot screens. Approximately 40 pounds of sand was poured around each well screen and the annular space was back-filled with drill cuttings. At some well sites two adjacent shallow wells were drilled to different depths. This was done because of the uncertainty of the position of the water table immediately following drilling. It was believed that if the shallower of the two wells did not contain water, the deeper well could be considered the watertable well. Where two wells are adjacent, the shallower of the two wells always contains water, so these are considered the water-table wells. Water levels in the deeper of the paired shallow wells are nearly always different (lower) than the adjacent water-table well. Because the deeper of the paired shallow wells are not water-table wells nor properly constructed piezometers, they are not used in the analysis.

A test hole was drilled to bedrock by rotary method during October 1978 to determine drift thickness and drift stratigraphy (table 2). Geophysical logs made in the open hole are shown in figure 6. A piezometer was constructed in the test hole using 2-inch steel pipe and 2-foot wire-wound screen. A petal cement basket was attached above the screen and enough cement was pumped in through a tremmie line to provide a 50-foot seal above the piezometer screen (fig. 7). Four additional piezometers, drilled by rotary method and spaced about 10 feet apart, were placed near the first piezometer during September 1979. These piezometers were constructed in the 


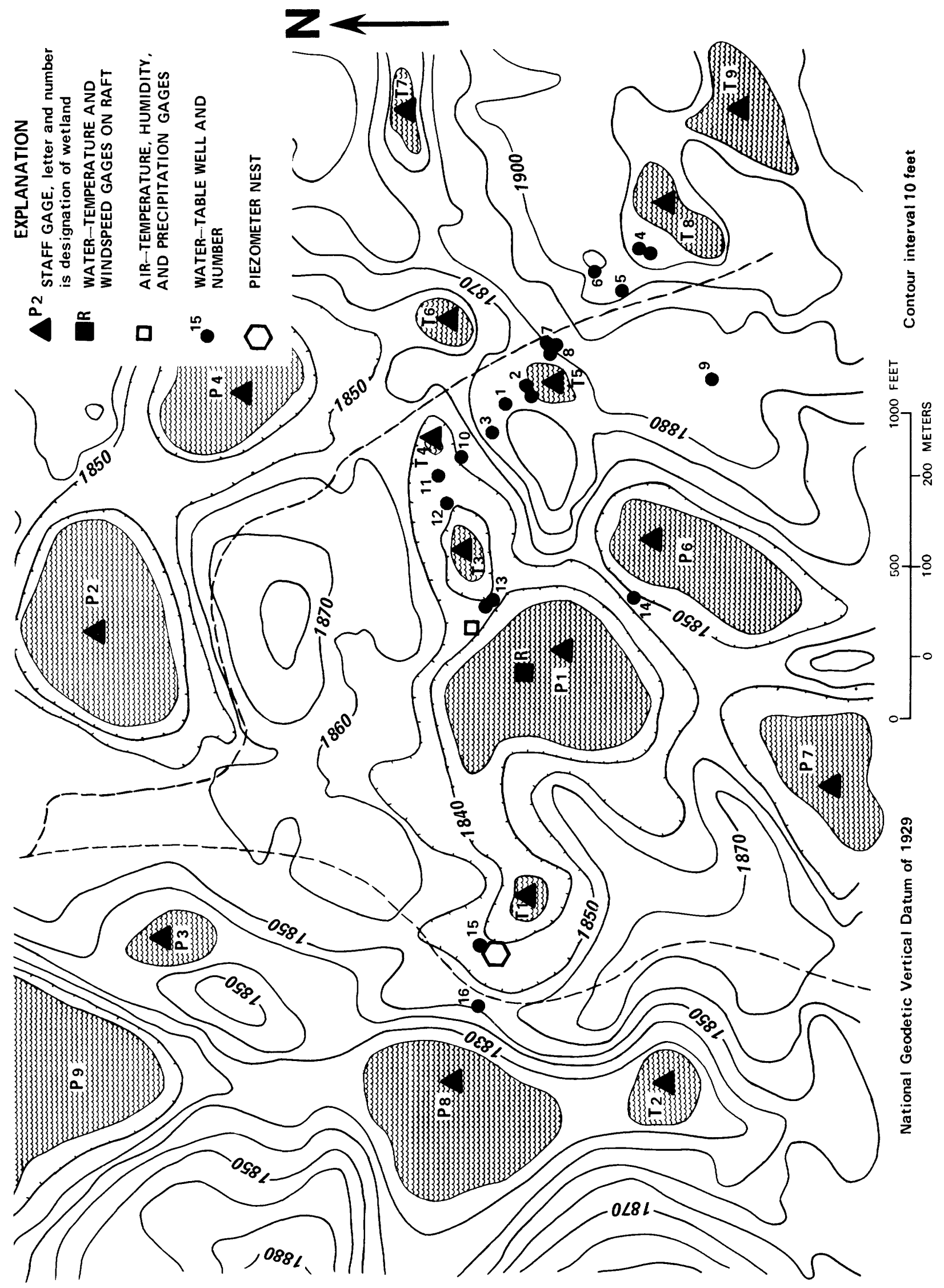




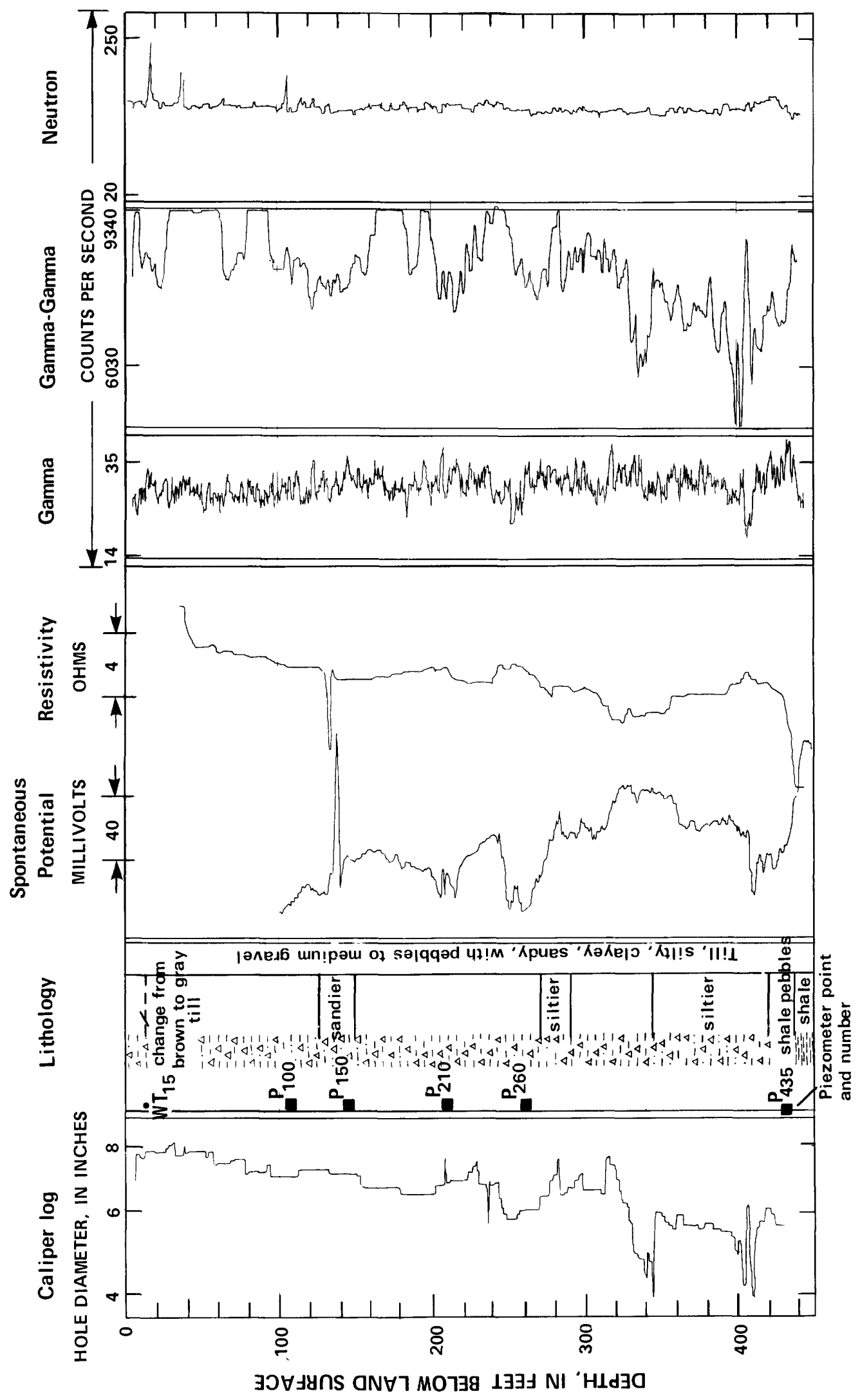

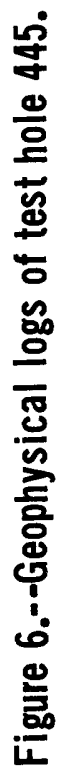




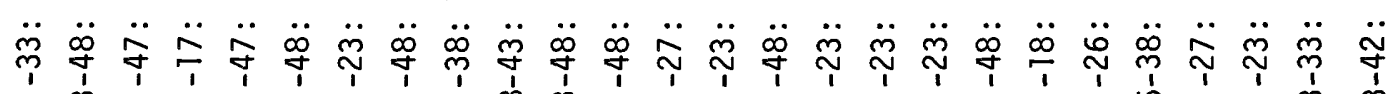

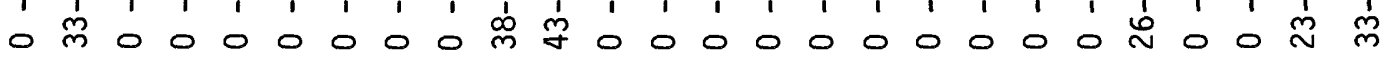

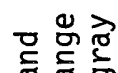

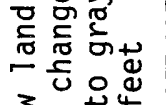

3.

范

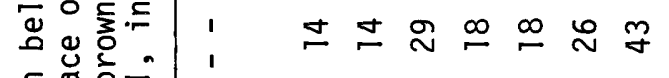

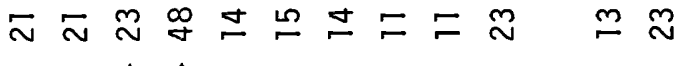

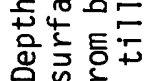

$\mathrm{Cu}_{4}$

4. 을

要芯

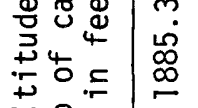

$\forall \sim m$ !

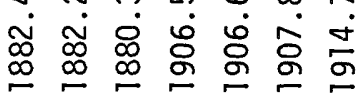

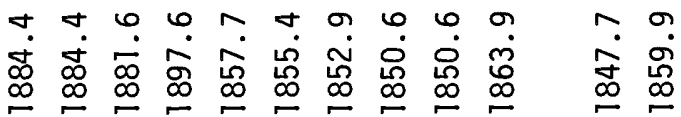

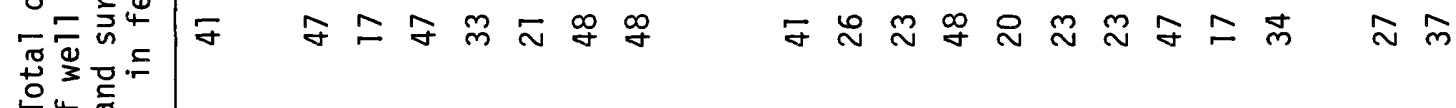

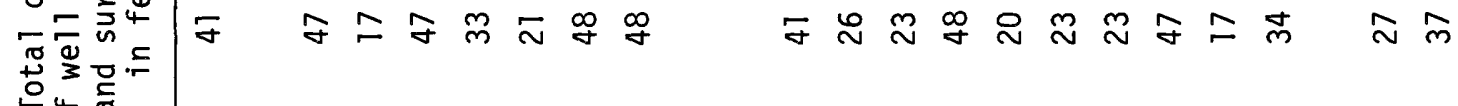

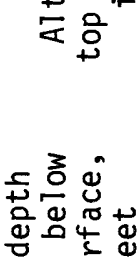

14

or

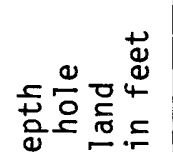

هั

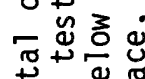

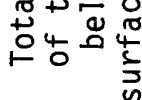

$\stackrel{\infty}{\sim} \stackrel{\infty}{\sim}$ f $\stackrel{\infty}{\sim} \stackrel{\infty}{\sim} \stackrel{\infty}{+}$

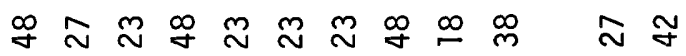

离旁

$\sim \sim m+i$ L 0

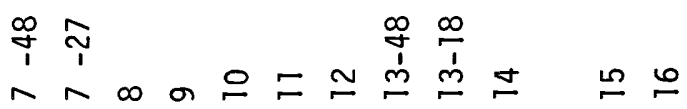




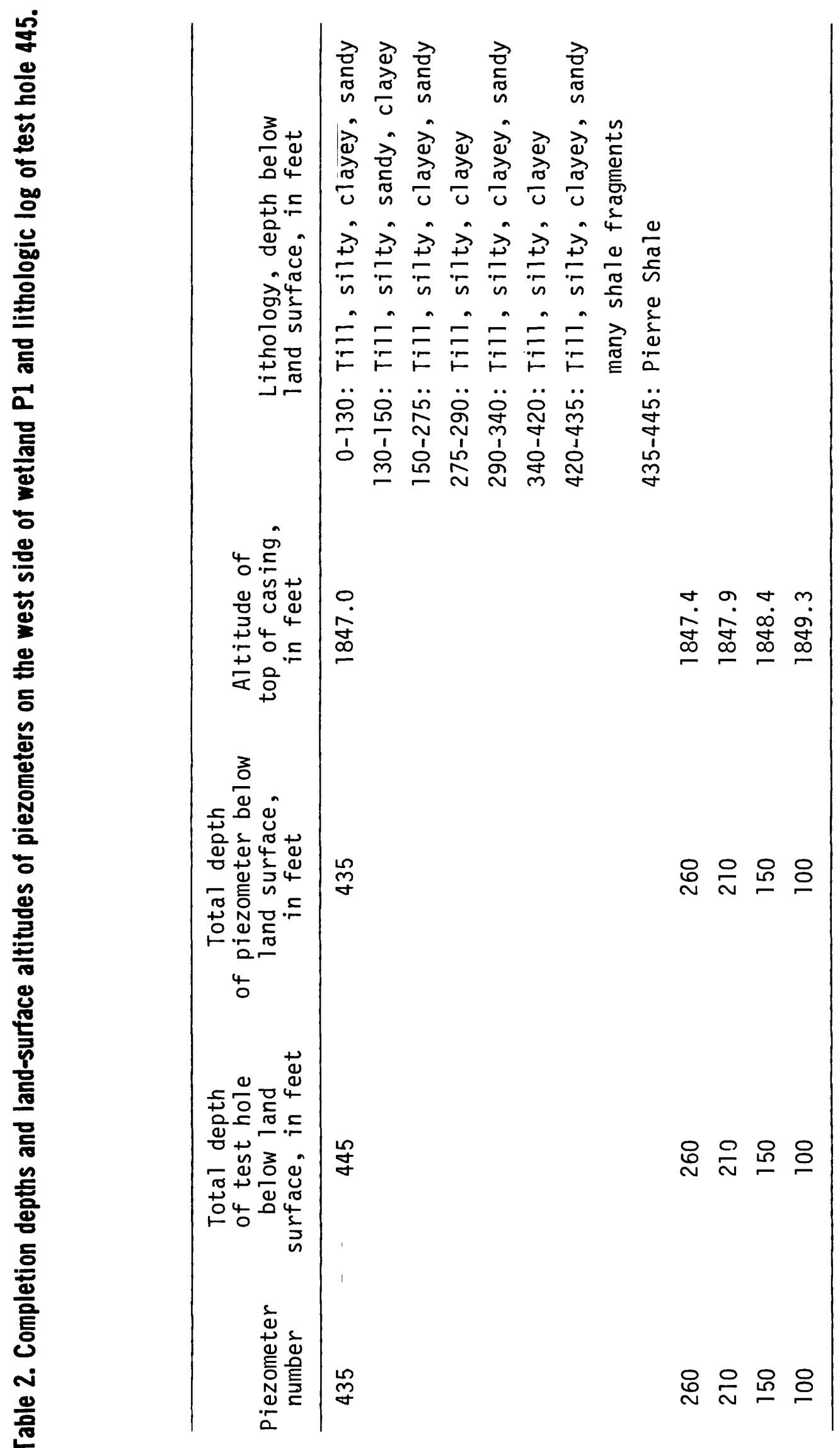




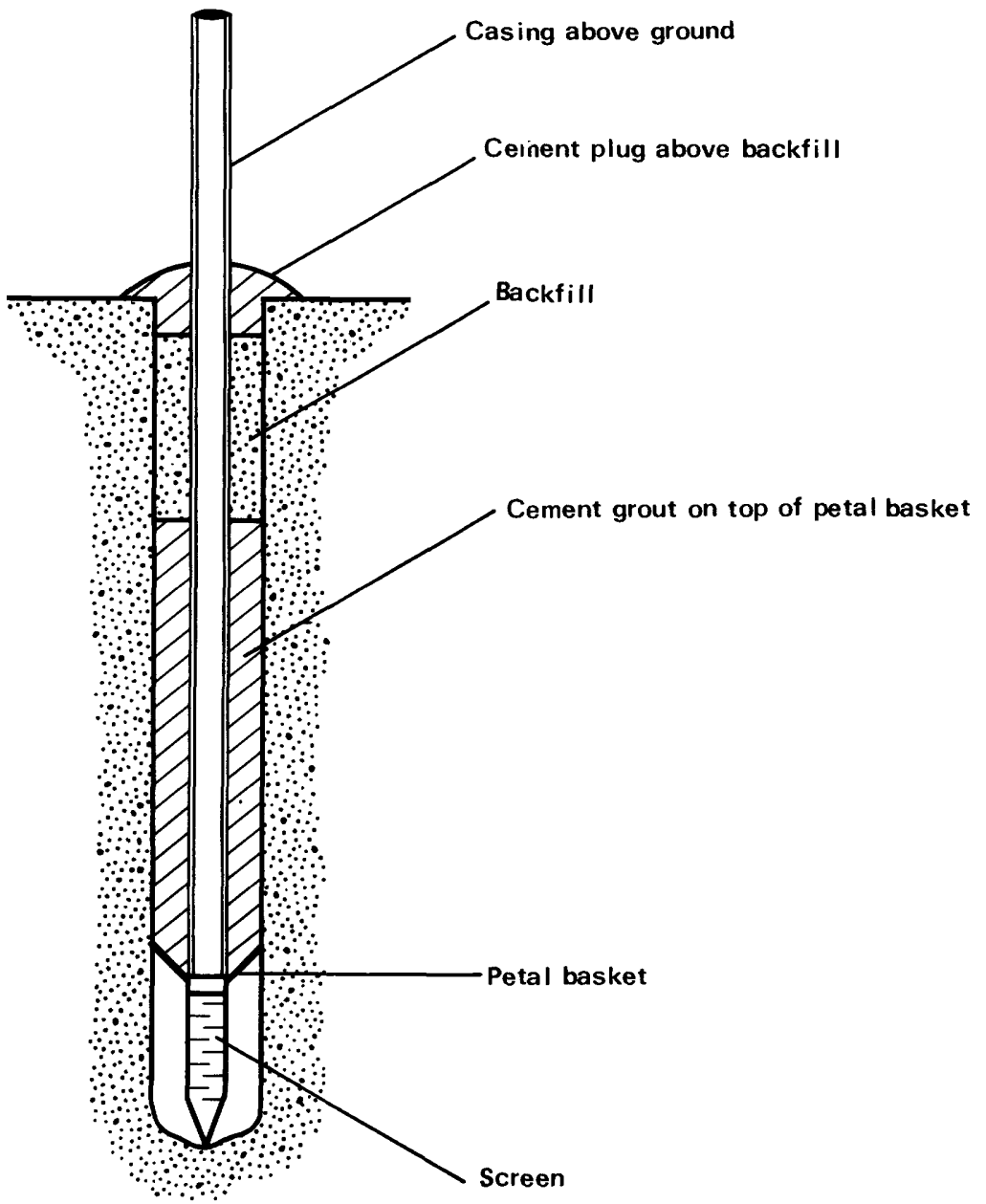

Figure 7.--Piezometer construction. 
same manner as the deep piezometer except plastic pipe and screens were used and check valves were attached to the bottom of each screen to aid in back flushing the drill hole prior to grouting.

Because there is no bench mark in the immediate study area, altitudes of all water-level installations (wells and staff gages) were determined by leveling relative to piezometer 435 (test hole 445). An arbitrary altitude of 1847.0 feet was assigned to this piezometer based on the best estimate that could be made from the topographic map. Therefore, although the altitudes of measuring points appear to be close to those on the topographic map, they are actually all relative to the arbitrary datum.

\section{Preliminary Analysis}

The hydrologic system is dynamic and analysis of data is meaningful only after at least several years of data are available. The following discussion of data collected to mid-October 1979 is based on a very short period of record, therefore the interpretations of the data are considered preliminary. The discussion is intended primarily to demonstrate the long-term study approach.

\section{Atmospheric Water}

Precipitation

Precipitation for a given site can be measured or estimated using a variety of techniques. The most accurate method is by using a recording gage at the study site. A hydrograph of precipitation at the study site from midJuly, when the recording gage was first installed, to mid-October 1979 is shown in the bottom graph of figure 8 .

Precipitation can also be estimated by interpreting data from gages remote from the site by a number of regionalization techniques. Data from National Weather Service gages are commonly used for this purpose. The National Weather Service gages closest to the Cottonwood Lakes area study site are at Jamestown, Arrowwood Dam, Woodworth, and Medina (fig. 9). Regionalization techniques commonly used are mean, weighted mean and isohyetal (fig. 9).

Based on the precipitation records for mid-July through mid-October 1979, from the four nearby National Weather Service stations (fig. 8), five 2-week periods were selected to compare precipitation estimates for the study site, as determined from regionalizing the National Weather Service data, with precipitation recorded by the recording gage at the study site (fig. 10). The bars show the deviation of the estimate from the recorded value, which is the zero base line on the graphs. Comparisons were made for both 14-day total precipitation and for the largest storm during each 14-day period. The period July 11-24, 1979, was selected to illustrate the methodology, including precipitation maps, used for each of the 14-day periods (fig. 9). 


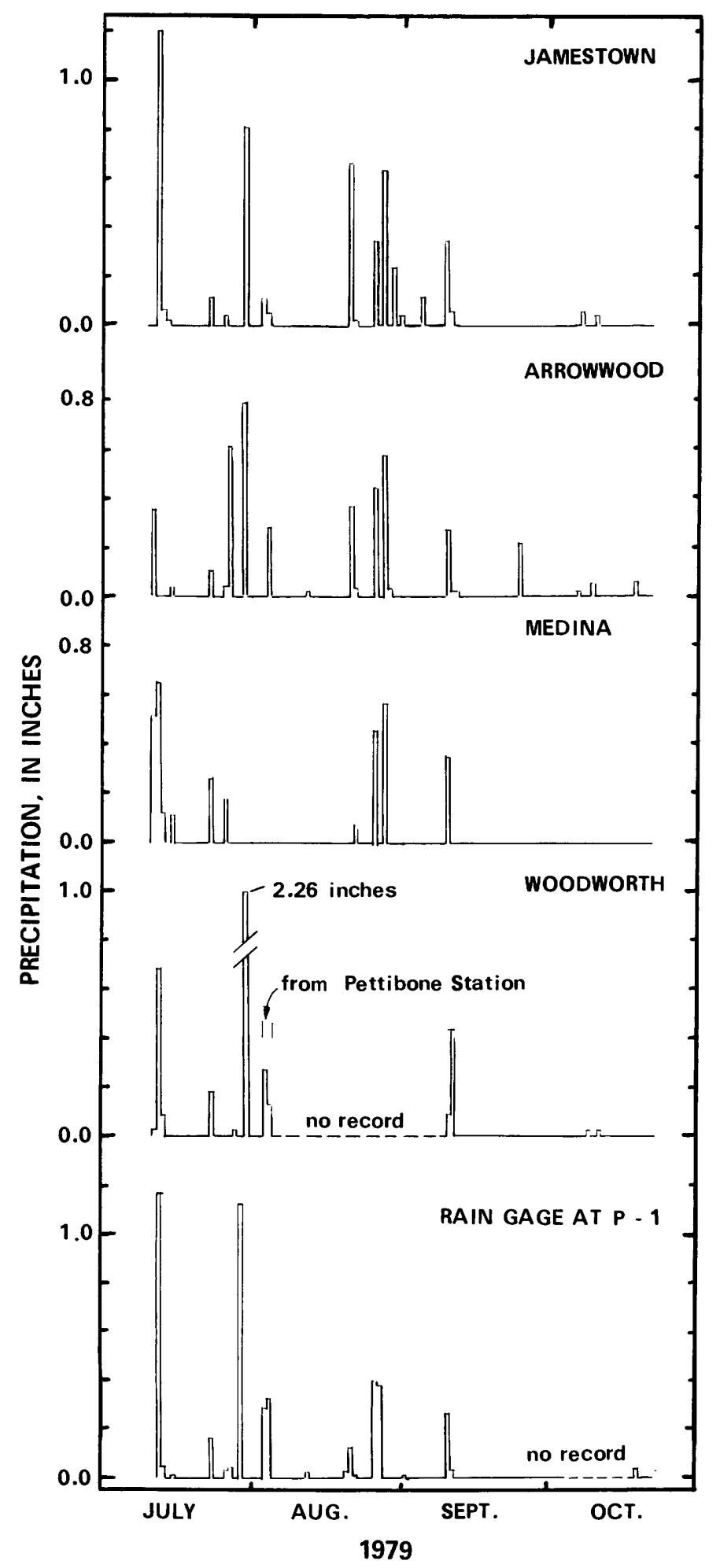

Figure 8.-Precipitation at the study site and at the four nearest National Weather Service stations, mid-July to mid-October 1979. 


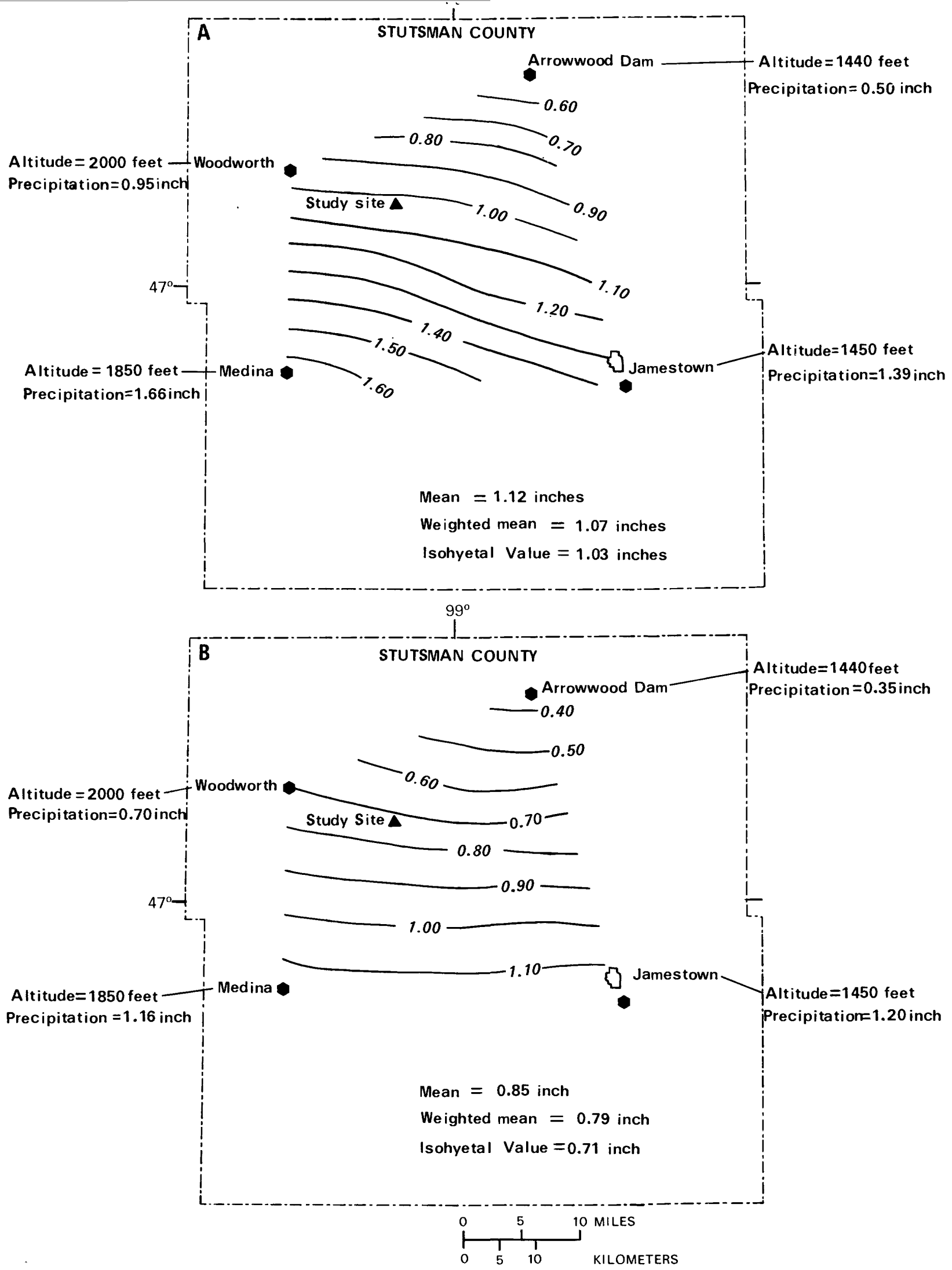

Figure 9.-Precipitation maps and comparison of three regionalization techniques to estimate precipitation at the study site from National Weather Service data, July 11-24, 1979. (A) 14-day total precipitation. (B) Largest storm during the 14-day period. 


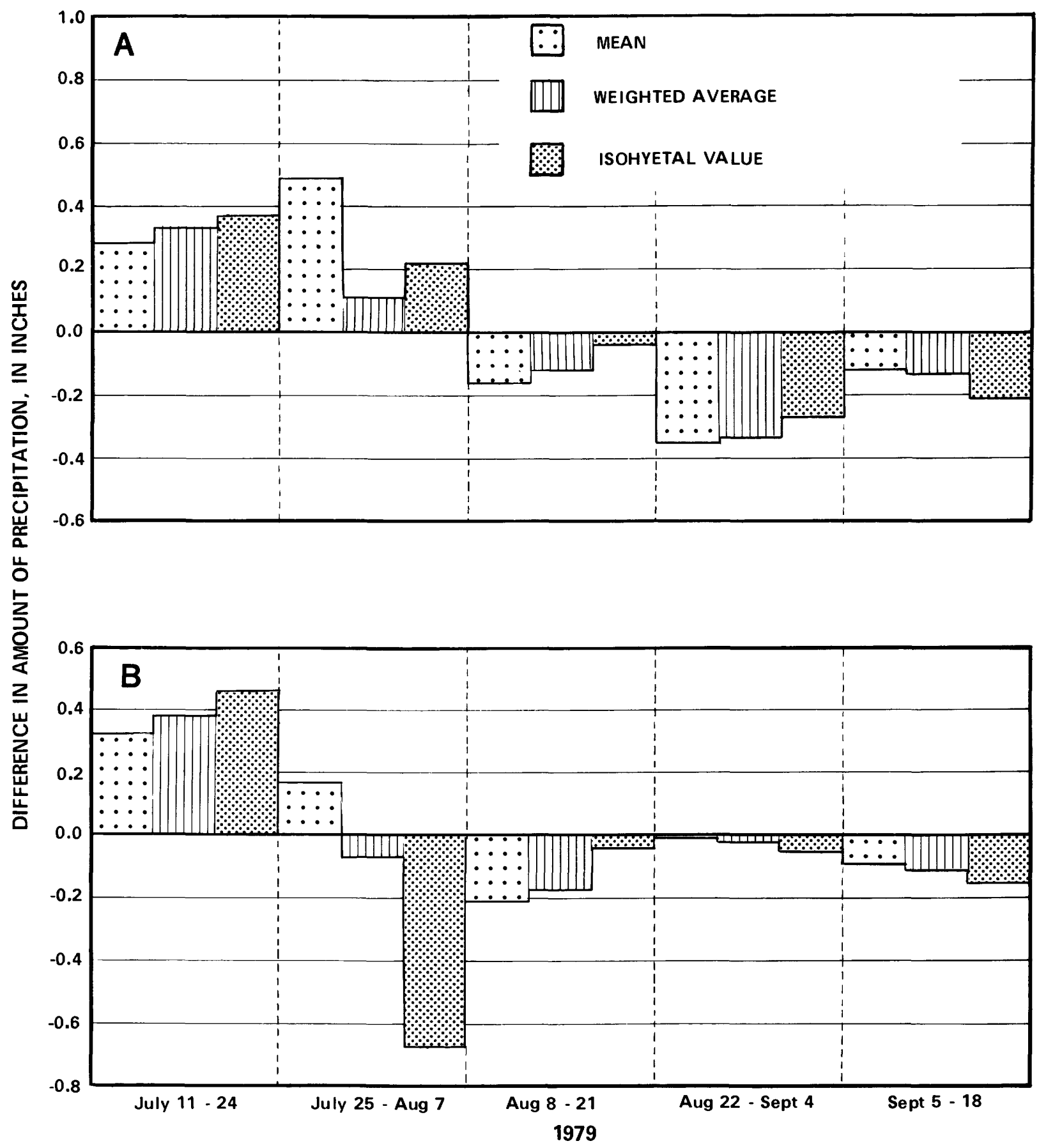

Figure 10.--Difference between precipitation as measured by the recording gage at the study site (the zero baseline) and that estimated by three regionalization techniques (bars) using National Weather Service data, mid-July to mid-October 1979. (A) Total precipitation for each 14-day period. (B) Largest storm during each 14-day period. 
Siegel and Winter (1980) discuss a comparison of the same regionalization techniques for estimating rainfall at Williams Lake, north-central Minnesota. In that study a network of National Weather Service gages located tens of miles from the lake and a network of observer-read gages located within 2.5 miles of the lake were compared to the rainfall measured by a recording gage at the lake. That study showed regionalized data from the close-by network of observers provided a relatively good estimate of rainfall for the lake, and gave better estimates of rainfall for the study site than information derived from the more distant National Weather Service gages.

\section{Evaporation}

Perhaps the best method for calculating evaporation is by an energy budget. This approach is seldom used however, because it requires measurement of the energy sources, sinks, and storage within the water body, and therefore requires considerable instrumentation. Calculation of evaporation by the energy-budget method will be done in later phases of these studies.

In some studies, evaporation from a lake is calculated by using data from an evaporation pan, then adjusting the value by applying a pan-to-lake coefficient. Many studies have been done evaluating pan evaporation and the use of pan-to-lake coefficients (Winter, 1981). A we11-run pan station needs to have daily service and for this reason use of pans is not feasible for the relatively remote Cottonwood Lake area study site. In addition, a pan-to-lake coefficient needs to be uniquely determined for each lake by comparison with an independent measurement of evaporation.

A commonly-used alternative approach to operating a pan at the study site is to use evaporation data from the nearest National Weather Service pan, then adjust the value by a pan-to-lake coefficient. Considering the uncertainty in pan data and the problems in selecting a proper pan-to-lake coefficient, use of National Weather Service pan data from stations a large distance from the lake of interest can be considered only an approximation. An estimate of evaporation for the study site, using data from the National Weather Service pan at Carrington (29 miles north), and applying the commonly-used pan-tolake coefficient of 0.7 , is given in table 3 . The coefficient 0.7 is applicable only for annual estimates, but in lieu of a better value at this point in the study, it is used here for comparison with preliminary mass-transfer estimates of biweekly and monthly estimates.

A mass-transfer method is another approach to estimating evaporation. For this method, few variables need be measured and reliable instruments are available. Data are needed for air and water temperatures, windspeed, and relative humidity. This method is being used at the study site, and data from the time of instrument installation (mid-July) to freezeup (late October) are shown in figure 11. The most difficult aspect of the masstransfer method is determination of the mass-transfer coefficient. 

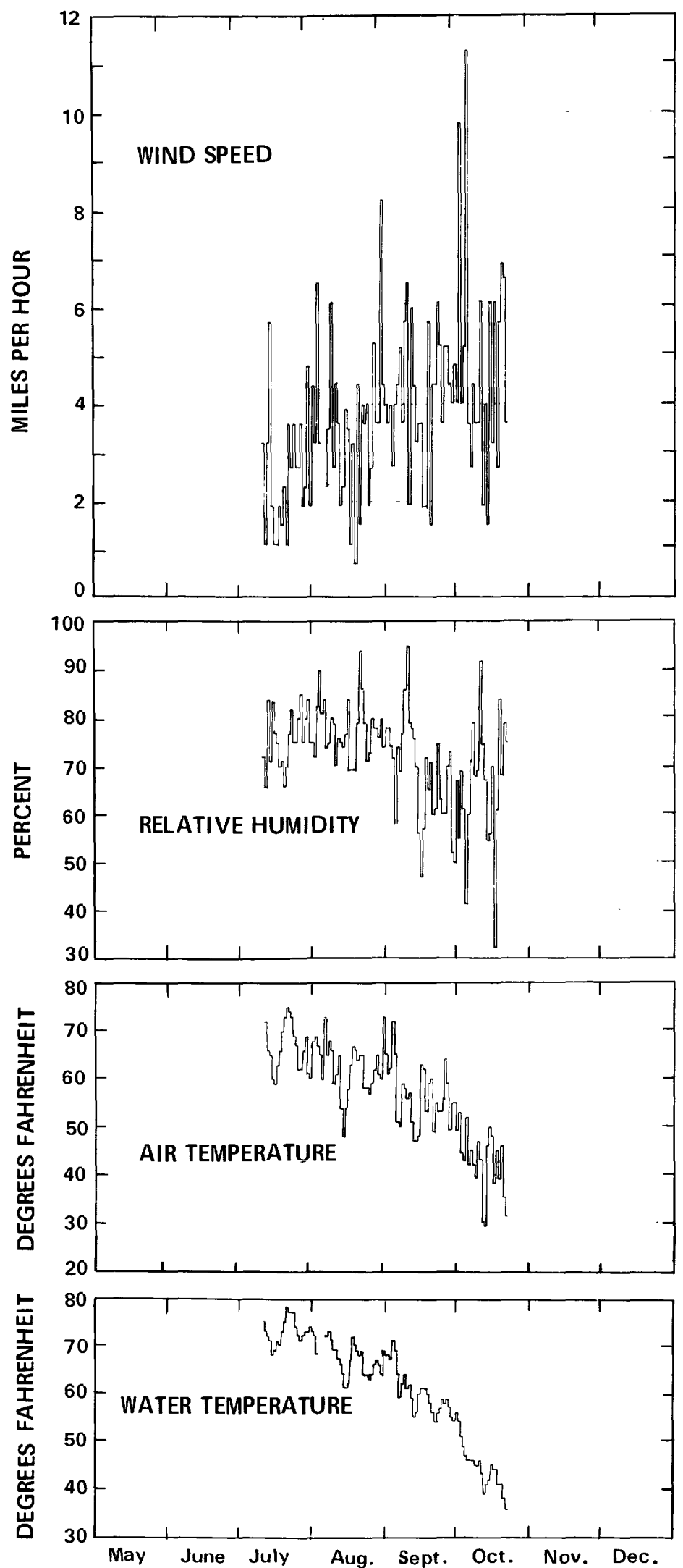

Figure 11.--Wind speed, relative humidity, air temperature, and water temperature at wetland P1. 


\section{Table 3. Comparison of two mass-transfer methods and one pan method for estimating evaporation from wetland P1, mid-July to mid-0ctober, 1979.}

\section{Mass Transfer Coefficient, $\mathrm{N}$ $0.00388 \quad 0.00306$ (from $\Delta H$ data) (from Harbeck, 1962)}

Evaporation pan, National Weather Service station at Carrington (29 miles north)

\begin{tabular}{llll}
\hline JuTy 12-31 & 3.16 & 2.41 & $5.07 \times 0.7=3.55$ \\
August 1-31 & 4.03 & 3.18 & $6.38 \times 0.7=4.47$ \\
September 1-30 & 4.31 & 3.40 & $6.26 \times 0.7=4.38$ \\
October 1-22 & 2.03 & 1.61 & NO DATA \\
\hline
\end{tabular}

In the mass-transfer equation:

$$
E=N u\left(e_{0}-e_{a}\right)
$$

where

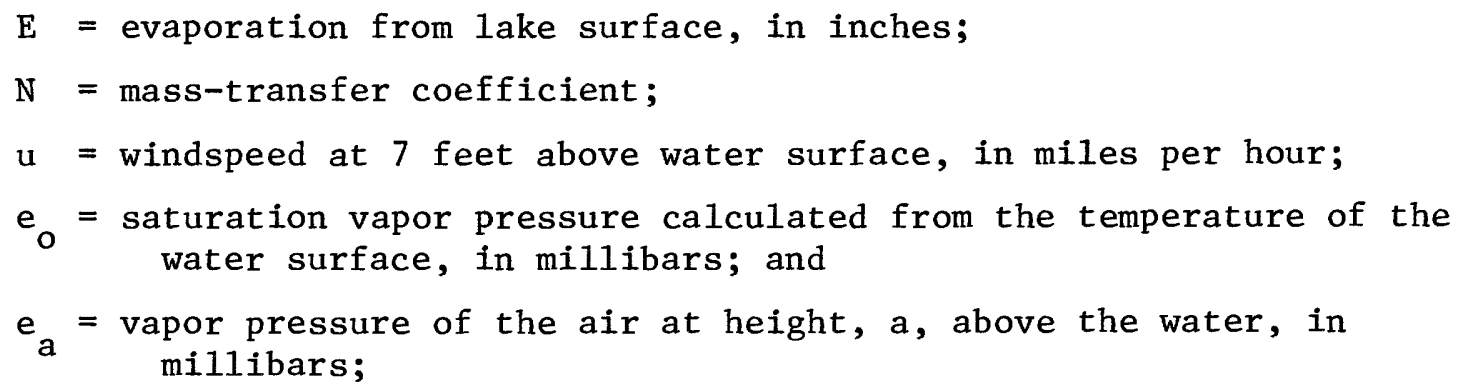

the mass-transfer coefficient (N) needs to be determined empirically and the remainder of the equation, termed the mass-transfer product, is calculated from the data shown in figure 11 . The best method of determining $\mathrm{N}$ is to relate the mass-transfer product to an accurate independent measurement of evaporation, such as the energy budget, and this will be done in later phases of these studies.

An alternative approach of estimating $\mathrm{N}$ is to relate the mass-transfer product to change in stage of the water body. To apply this method, data needs to be collected during periods of no additions or deletions of water to the water body, such as by precipitation or surface inflow or outflow. An 
attempt was made to estimate $\mathrm{N}$ by this method, but because it is a regression technique and because the period of record is very short, few data points are available. The necessity of a recording gage on the surface-water body (wetland P1) was clearly demonstrated in the attempt to use this method of estimating $\mathrm{N}$ because close time control is needed on the response of wetland water levels to precipitation. The estimate of $\mathrm{N}$ (table 3 ) using this technique has considerable error, but it is included in this report simply to show one of the approaches that will be evaluated in these wetland hydrology studies.

For comparison, a third approach to estimating $\mathrm{N}$ is by the functional relationship suggested by Harbeck (1962). In this approach, $N$ is determined from surface area of the water body. The $N$ value for wetland $P 1$, and comparative estimates of evaporation from mid-July to late October 1979 using both the mass-transfer and pan methods, are shown in table 3 .

\section{Surface Water}

The wetlands of interest in this study, particularly $\mathrm{P} 1$, have no openchannel streamflow interacting with them. The surface-water information of interest to this study is related solely to fluctuation and altitudes of water levels in the wetlands. Hydrographs of water levels in nine wetlands in the study area are shown in figure 12 .

\section{Ground Water}

In considering the interaction of ground water with lakes and wetlands in the prairie environment, an evaluation of regional ground-water flow will be used to put the local site studies in perspective. Water-table altitude information from the water-table wells constructed for this study (fig. 13) indicate water-table highs do not always underlie land surface highs on a local scale, but on a broad regional scale this assumption can be made.

\section{Regional Ground-Water Flow}

To develop a general concept of ground-water flow in the Missouri Coteau region near the study site, data from the Stutsman County (Huxel and Petri, 1963) and Kidder County (Randich and others, 1962) ground-water studies were used to construct a hydrologic profile through the part of the Coteau shown in figures 3 and 4. Similar types of regional analyses have been done by Meyboom (1963), Maclay and others (1972), and Van Voast and Novitzki (1968).

Because of the limited number of data points available for contouring hydraulic head in the vertical dimension, it is possible to develop two conflicting interpretations of the same field data. For example, figure 14A shows a downward hydraulic-head gradient nearly everywhere along the section, 

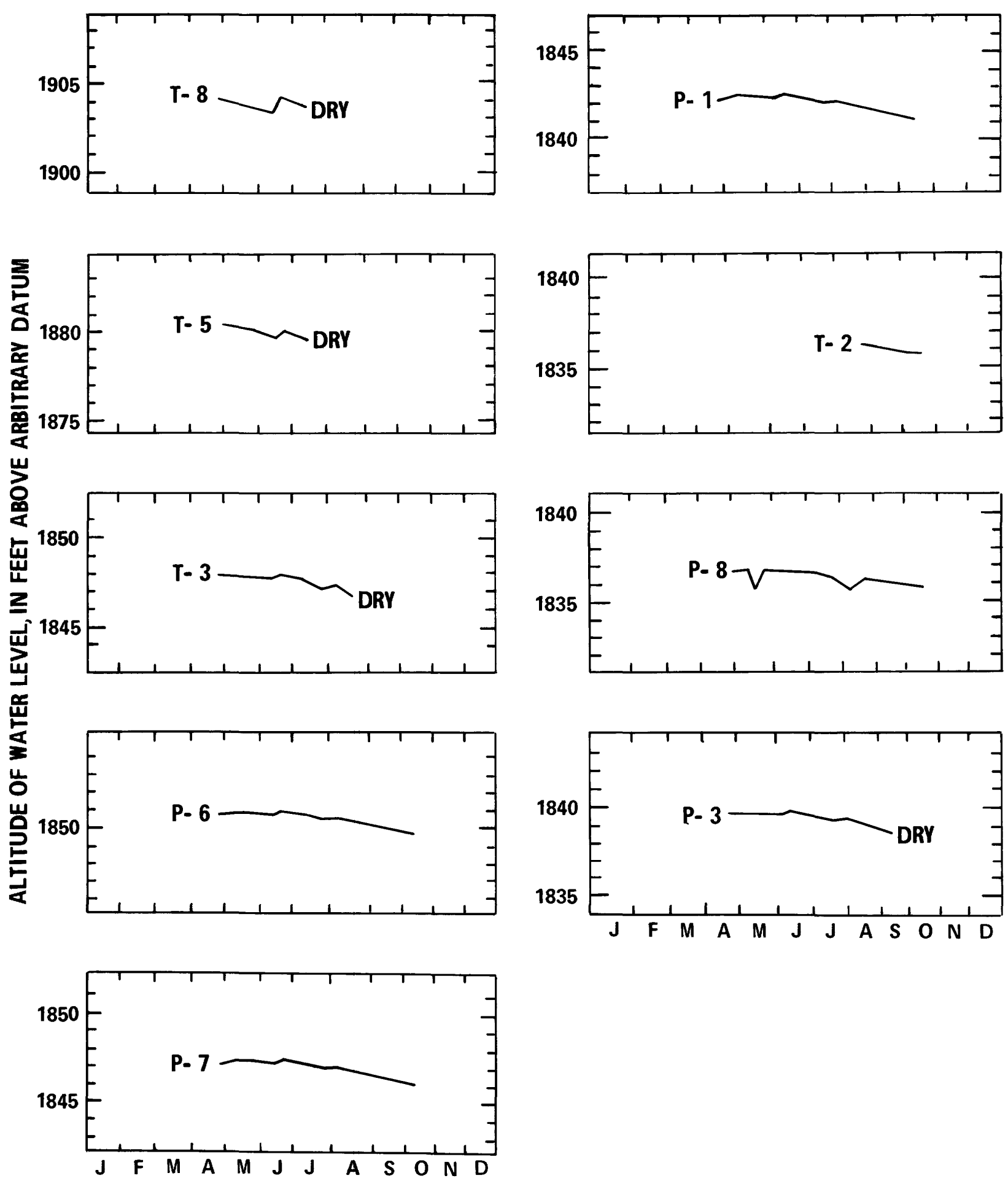

Figure 12.--Hydrographs of water levels in selected wetlands at the study site. 

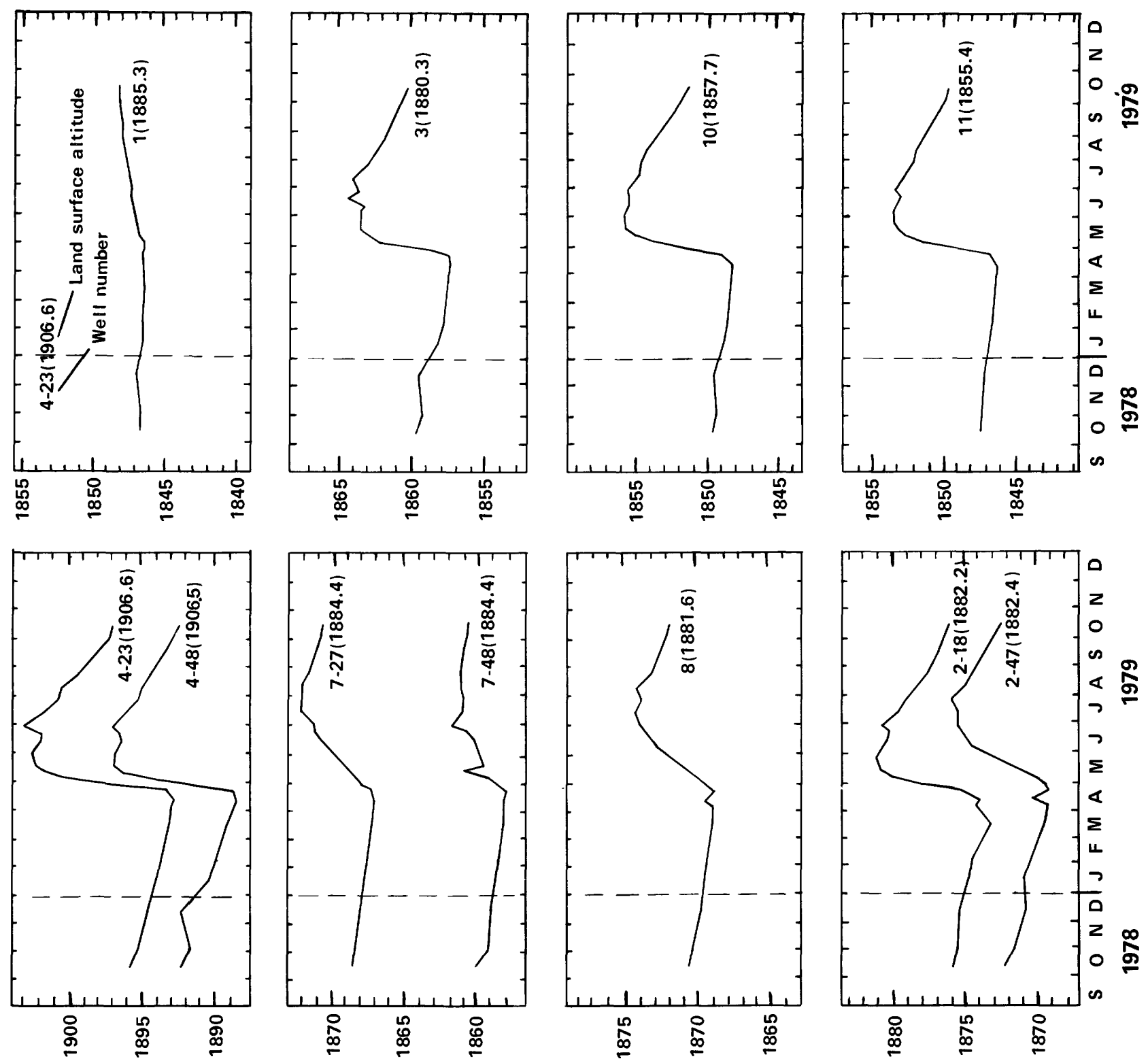

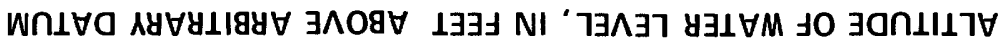



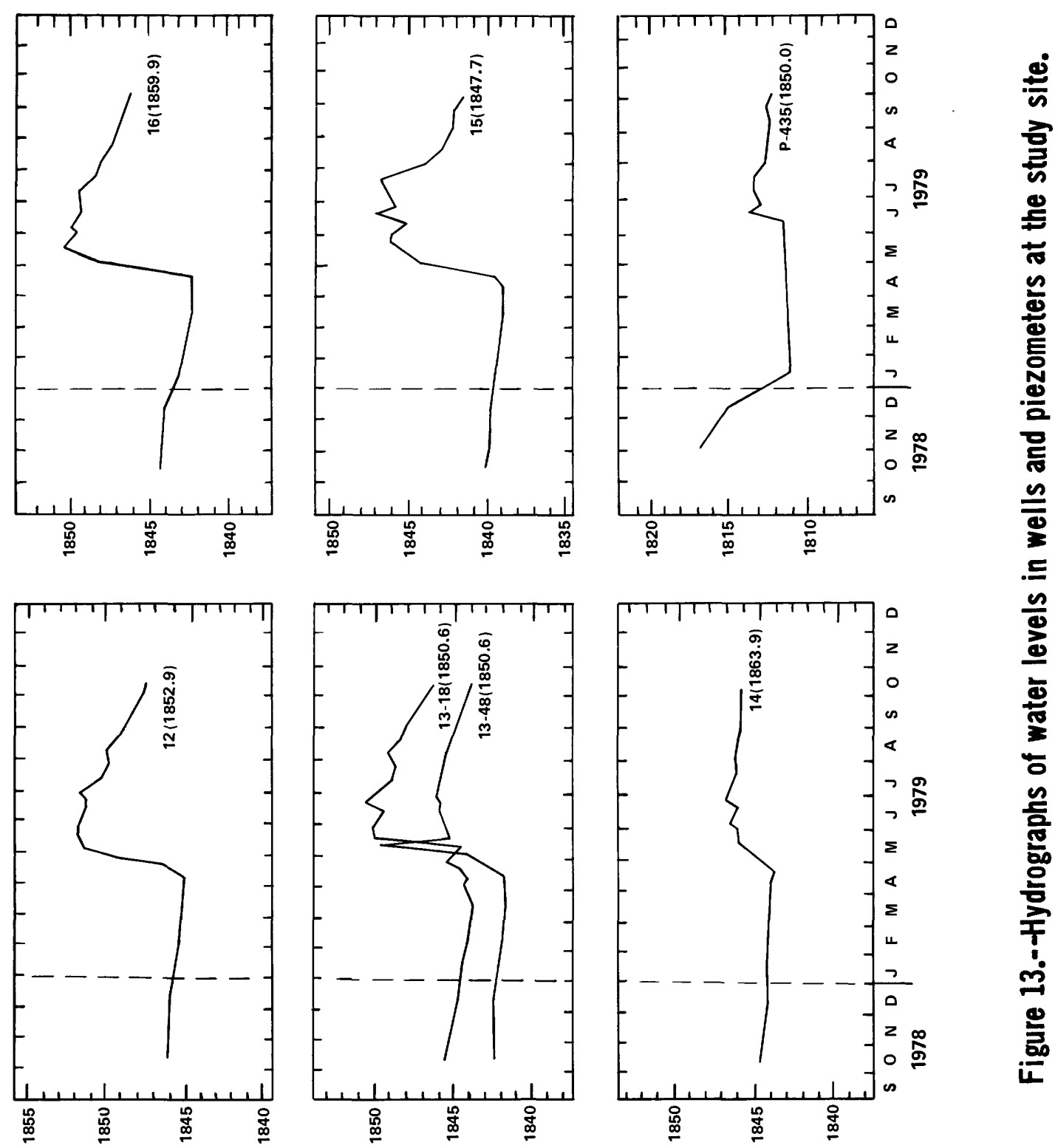

.5

$\frac{\infty}{9}$

은

홍

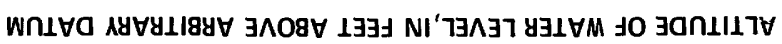



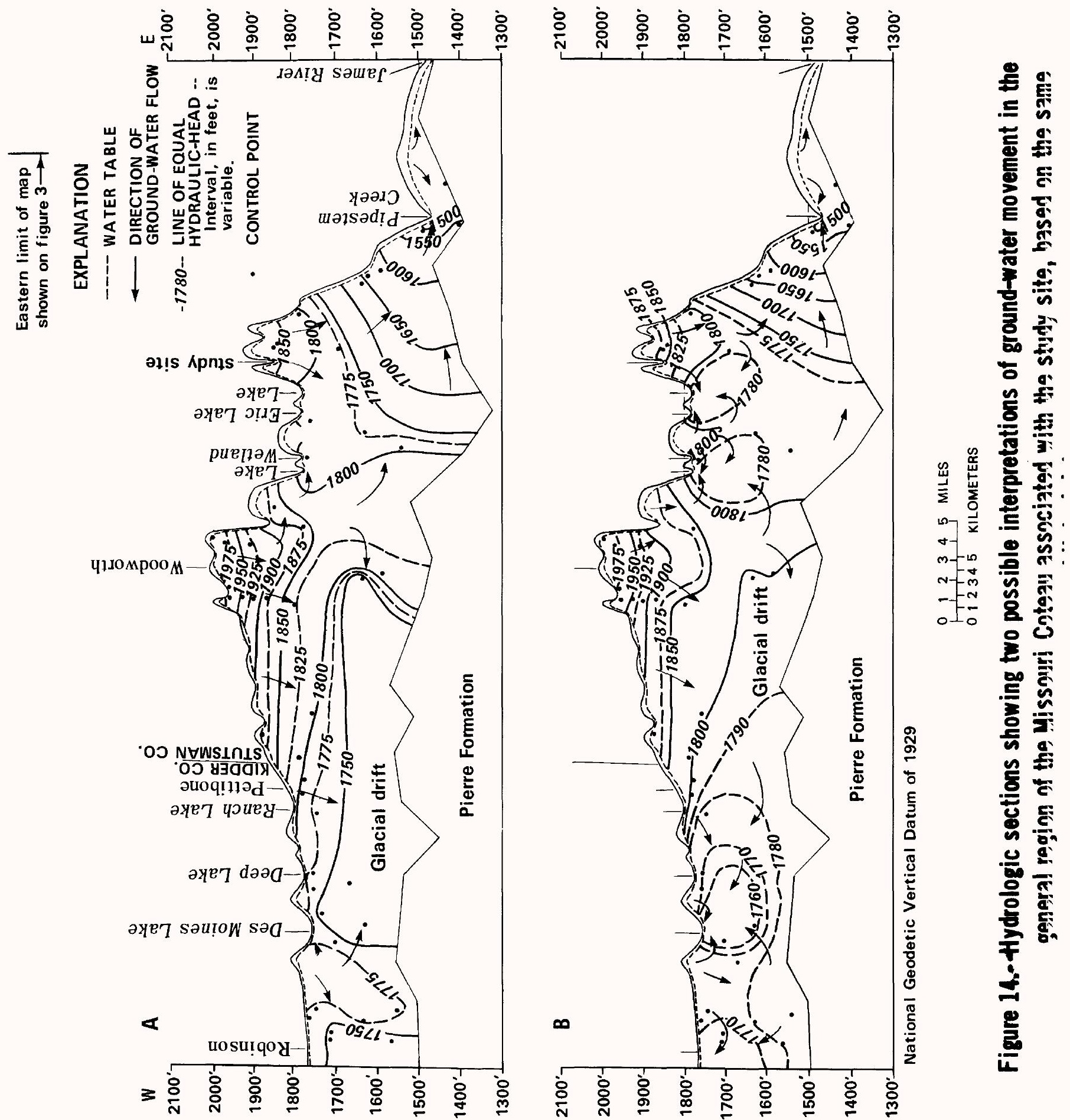
even in the topographically low areas. In contrast, figure 14B shows downward hydraulic-head gradients in the topographically high areas and large ground-water discharge areas (upward gradient) in the topographically low areas. In both instances it is not possible, because of limited data, to examine small local flow systems near the smaller water-table highs and lows. To help resolve the conflicting interpretations and to examine the smallerscale flow systems, it was decided to use numerical simulation experiments which permit improved conceptualization of ground-water flow systems for given situations.

Hydrogeologic factors that affect ground-water flow include: (1) Geometry of the geologic framework through which ground water flows, including the overall boundaries and the distribution of geologic units within those boundaries; (2) hydraulic conductivity of the geologic materials, including the anisotropy--the ratio of vertical to horizontal hydraulic conductivity; and (3) recharge and discharge (sources and sinks) of the groundwater system.

Concerning the geometry of the ground-water system to be modeled, for purposes of this study these characteristics are generally known. The sides of the section (fig. 15) are considered no-flow boundaries because: (1) The James River on the east side is considered a major ground-water sink such that no ground-water passes beneath it within the drift, and (2) the topographic low on the west edge of the section is considered a no-flow boundary because the 1and (and water table) to the west of the section rises to altitudes equivalent to those in the modeled section, therefore by image theory it is assumed no ground water passes out of the west side of the section. The underlying Pierre Formation is considerably less permeable than the drift, therefore it acts as a no-flow boundary along the base of the section.

The distribution of lithologic units within the drift, as shown in the sections (fig. 15), are interpreted from data given in the county groundwater studies cited earlier. The hydraulic conductivity of the geologic materials are not well known but, again, for purposes of this study the values used in the simulations are commonly used in studies of the type of till and outwash found in the study area.

Recharge and discharge of the ground-water system is reflected by fluctuations of the water table, the upper surface of the ground-water system. Although the water table is clearly dynamic on a local scale (fig. 13), the magnitude of fluctuation is small relative to the total thickness of the ground-water system therefore a steady-state assumption is reasonable for regional analyses--an assumption also justified by Freeze (1969).

The on1y hydrogeologic parameter needed for simulation of the hydrologic sections considered in this report that is unknown for most deposits is anisotropy. Because values of this parameter are not available, a number of sections were analyzed by computer experiments in which anisotropy was varied so the sensitivity of the results to this parameter could be evaluated. 
Anisotropy is the only parameter changed in the three hydrologic sections shown in figure 15.

It also is important to recognize the significance of stagnation points in vertical-flow-system analysis. A stagnation point in a ground-water flow field is a point of no fluid movement. In addition, although it is the point of least hydraulic head along a flow-system boundary, it always has a hydraulic head greater than that represented by the contiguous surface-water body. Thus, if a stagnation point exists, it indicates the flow-system boundary is continuous and all ground water within the flow-system boundary moves into the surface-water body. Seepage from the surface-water body cannot occur. (See Winter, 1976; 1978a for graphical demonstration of this.)

Two-dimensional vertical-section analysis is believed justified for regional analysis because the line of section is perpendicular to the long linear configuration of the Missouri Coteau.

A finite-element ground-water flow model developed by R. L. Cooley (U.S. Geological Survey, written communication, 1980) was used to solve the groundwater flow equation:

$$
\frac{\partial}{\partial x}\left[K(x, z) \frac{\partial h}{\partial x}\right]+\frac{\partial}{\partial z}\left[K(x, z) \frac{\partial h}{\partial z}\right]=0
$$

where

$$
\begin{aligned}
& \mathrm{K}(\mathrm{x}, \mathrm{z})=\begin{array}{l}
\text { hydraulic conductivity in the two coordinate directions, in feet } \\
\text { per day; and }
\end{array} \\
& \frac{\partial \mathrm{h}}{\partial \mathrm{x}}, \frac{\partial \mathrm{h}}{\partial z}=\text { gradients of hydraulic head (dimensionless). }
\end{aligned}
$$

To solve the equation, the following assumptions, in addition to those stated above, were made: The soil and water are incompressible, fluid density is constant, the coordinate axes are alined collinear with the principal components of the hydraulic-conductivity tensor.

Although the modeled sections are not intended to be definitive representations of actual ground-water flow in the Missouri Coteau region (recall, their purpose for this report is merely to help develop concepts), they show a number of interesting aspects of flow systems that could conceivably exist in this region. Results of numerical simulations show a major regional ground-water recharge divide exists beneath the highest point on the water table (the Woodworth area) for the entire range of anisotropies considered (between 100 and 1,000 ). The presence of a regional stagnation point at the base of the section beneath Woodworth indicates that ground water moves both east and west from this point, and no water passes at depth either east or west beneath this area. 


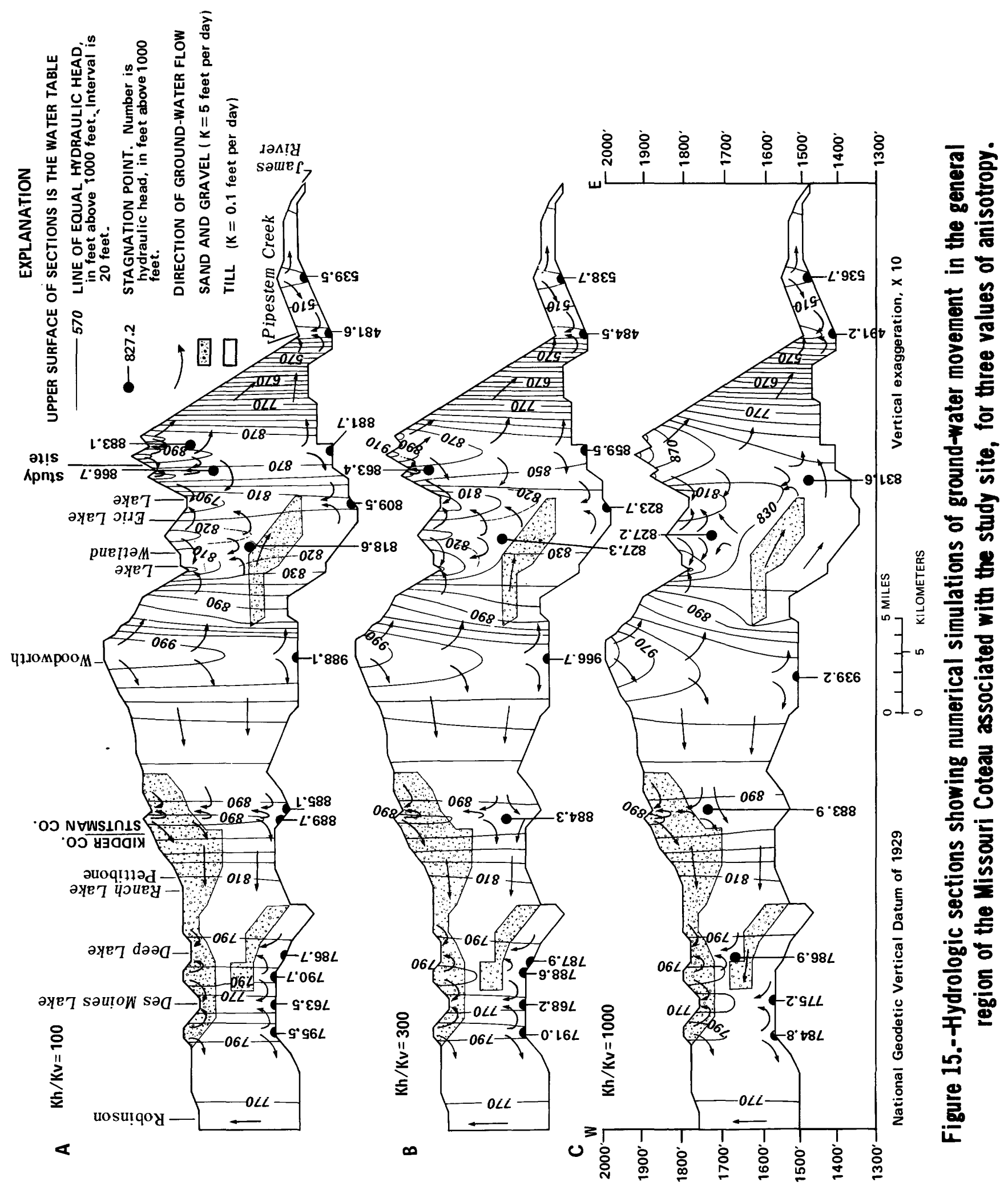


To the west of the Woodworth area, the sections show a water-table mound near the Stutsman-Kidder County line. If the anisotropy of the system is 100 (fig. 15A) the water-table mound causes a hydraulic-head barrier to extend to the base of the ground-water system, as evidenced by the stagnation point and direction of flow at the base of the section. This indicates that there is no regional flow passing to the west beneath this area--a11 the ground water beneath the Woodworth area and the water-table mound east of the county line discharges to the lowland. If the anisotropy is greater, for example 300 (fig. 15B), this is no longer true. Although the local flow system extends deep into the ground-water system, a small amount of ground water passes to the west beneath the local ground-water flow system. (A local ground-water flow system is defined as ground water that is recharged at a water-table high and that discharges to an adjacent water-table low). If the anisotropy is 1,000 (fig. 15C), the local ground-water flow system extends to a little less than one-half the depth of the ground-water system.

Moving farther westward to the relatively 1ow, sandy part of the area, it is seen that the effect of the water-table mound west of Des Moines Lake is sufficiently great to cause a local flow system to form that extends the full thickness of the ground-water reservoir for all the anisotropies considered. The water-table mound between Des Moines and Deep Lakes is sufficiently high to cause a local flow system to extend the full thickness of the ground-water system if the anisotropy is 100 or 300 (figs. 15A and 15B), but if the anisotropy is as much as 1,000 , the local flow system extends on $1 \mathrm{y}$ to the top of the deep aquifer (fig. 15C). Regional flow passes beneath that local flow system and discharges into the Des Moines Lake lowland.

To summarize the above results, the simulations indicate that if the anisotropy of the glacial deposits is 100 . or less, there is no regional groundwater flow to the west of the Woodworth area, a11 the ground water is confined to local flow systems. If the anisotropy of the deposits is about 300 , a small amount of ground water that recharges in the Woodworth area passes at depth beneath the local flow system associated with the depression near the Kidder-Stutsman County line, and discharges at the Deep Lake lowland. If the anisotropy is as much as 1,000 , regional ground-water flow also passes at depth beneath the Deep Lake 1owland and discharges into the Des Moines Lake lowland.

The lowlands that lie to the east of the Woodworth area, between Woodworth and the high on which the study site lies, receive ground-water discharge from large local ground-water flow systems for all values of anisotropy considered. The high area that includes the study site creates a large hydraulic-head barrier that prevents regional ground-water flow from passing beneath it for anisotropy of 100 and 300 (fig. 15A and 15B). Even if the anisotropy is as much as 1,000 ( $\mathrm{fig} .15 \mathrm{C}$ ) only a small amount of regional ground-water flow passes at depth beneath the large local flow system associated with the study-site high. This indicates that the part of the ground-water system that contributes to Pipestem Creek is predominately from the east side of the high where the study site is located. 
It is of interest to the hydrologic studies of wetlands in the Cottonwood Lake area to use the numerical simulation experiments to examine the small local flow systems in the high on which the study site occurs. If the anisotropy is 100 (fig. 15A), the presence of stagnation points indicate closed local flow systems are associated with the small depressions on both sides of the highest point. (The study site discussed in the next section of this report lies on the western side of this highest point.) For the depressions that contain wetlands, the presence of stagnation points would indicate closed local flow systems, thus there could be no seepage from them.

If anisotropy is 300 ( $\mathrm{fig}$. 15B), there is no longer a stagnation point associated with the eastern small depression, therefore, a water body in that depression would probably have seepage from it. The western small depression still has a stagnation point, thus it is still a closed ground-water flow system. The reason for the difference between the two is probably related to the slope of the water table and depth to the next lower break in slope, as discussed by Winter (report in review). The stagnation point, which indicates a closed local ground-water flow system, persists at the western small depression at even greater anisotropies but it has a successively lower head with increasing anisotropy and the local flow system becomes smaller. If the anisotropy is 1,000 ( $\mathrm{fig}$. 15C), the stagnation point does not appear to exist, but if a finer grid spacing was used in the simulation, there might still be a very small closed local flow system in this area.

It is clear from this preliminary analysis of regional ground-water flow that it is essential to know the anisotropy of the glacial deposits in the Missouri Coteau area. If anisotropy is relatively sma11, there is less likelihood of seepage (and ground-water recharge) from wetlands that occur topographically high, provided there is a water-table mound on their downgradient side, than if the anisotropy is relatively large. To obtain values of anisotropy is one of the primary reasons the U.S. Geological Survey decided to begin field studies of the interaction of lakes and ground water.

The modeled sections (fig. 15) tend to support the interpretation of data shown in figure 14B. That is, large local and intermediate groundwater flow systems discharge into the topographic lows, regardless of the anisotropy of the system. This interpretation is further supported to some extent by field evidence because: (1) It helps explain the high salinity of the lakes in the topographically low areas, which probably receive considerable ground water inflow, some of which may be significantly mineralized, and (2) it seems unlikely that Pipestem Creek, (a very small, slow-moving creek) receives the relatively large amount of ground-water discharge indicated in figure 14A, where the entire ground-water system east of the Woodworth area would discharge to the creek.

Local Ground-Water Flow And Interaction With Wetlands At Study Site

The water-table well network for the initial phase of study was designed to obtain some concept of the water-table configuration along a topographic 
profile from the highest part of the study area to the lowest. Construction of additional water-table wells to provide definition of the areal configuration of the water table will be accomplished in subsequent studies. Because of the profile approach in the first phase of this study, the water-table maps shown in figure 16 show limited areal coverage and are of value largely in support of the hydrologic sections shown in figure 17 . The sections discussed in the following text have a vertical exaggeration of 5 times so the details of the water table can be discussed. To give a true perspective of the topographic relief involved, figure 17A shows the land surface profile with no vertical exaggeration.

The following discussion is of the interaction of wetlands and ground water along the line of section shown in figure $16 \mathrm{~A}$ and is based on data only for the 1979 open-water season. Ground-water flow simulations of the local study area were not made at this time because at this scale it is difficult to justify steady-state analysis. With a longer term and more complete data base, simulations of transient flow will be more realistic, and this type of analysis will be given highest priority in subsequent years of this study.

Ground-water conditions at the study site at the end of winter recession, just prior to the spring rise of the water table (see fig. 13) are shown in figure 17B. There were no staff-gage data for this date (Apri1 10).

By April 25 all the wetlands held water and the water table rose in a11 wells (fig. 17C). By May 31 the water table reached the first of two highest (but approximately equa1) levels for the year (fig. 17D). (See. fig. 16A for the areal configuration of the water-table on this date.)

Examining the hydrologic profile from the topographically highest part to the topographically lowest part as the year progressed, it is interesting to note that a water-table mound never formed on the downgradient side of $\mathrm{T} 8$, indicating that this wetland has seepage from it on its downgradient side whenever it holds water. The last measuring date that wetland $\mathrm{T} 8$ held water was July 12 (fig. 17E).

We11 5 has never contained water--either because the water table is below it or because it is improperly constructed. It is important to keep the large vertical exaggeration in mind because the slope of the water table, if it does occur below the well, is not nearly as steep as suggested by figures $17 \mathrm{~B}-\mathrm{G}$.

Wetland T5 shows a water-table gradient away from it on both the upgradient and downgradient sides for the entire period it holds water. Like wetland T8, the last measuring date that T5 held water also was July 12 (fig. 17E).

Water-level information from wel1 1 shows a depression in the water table similar to that near well 5. Data from we11 1 show a relatively dampened water-level response compared to some of the other water-table wells, 


\section{EXPLANATION}
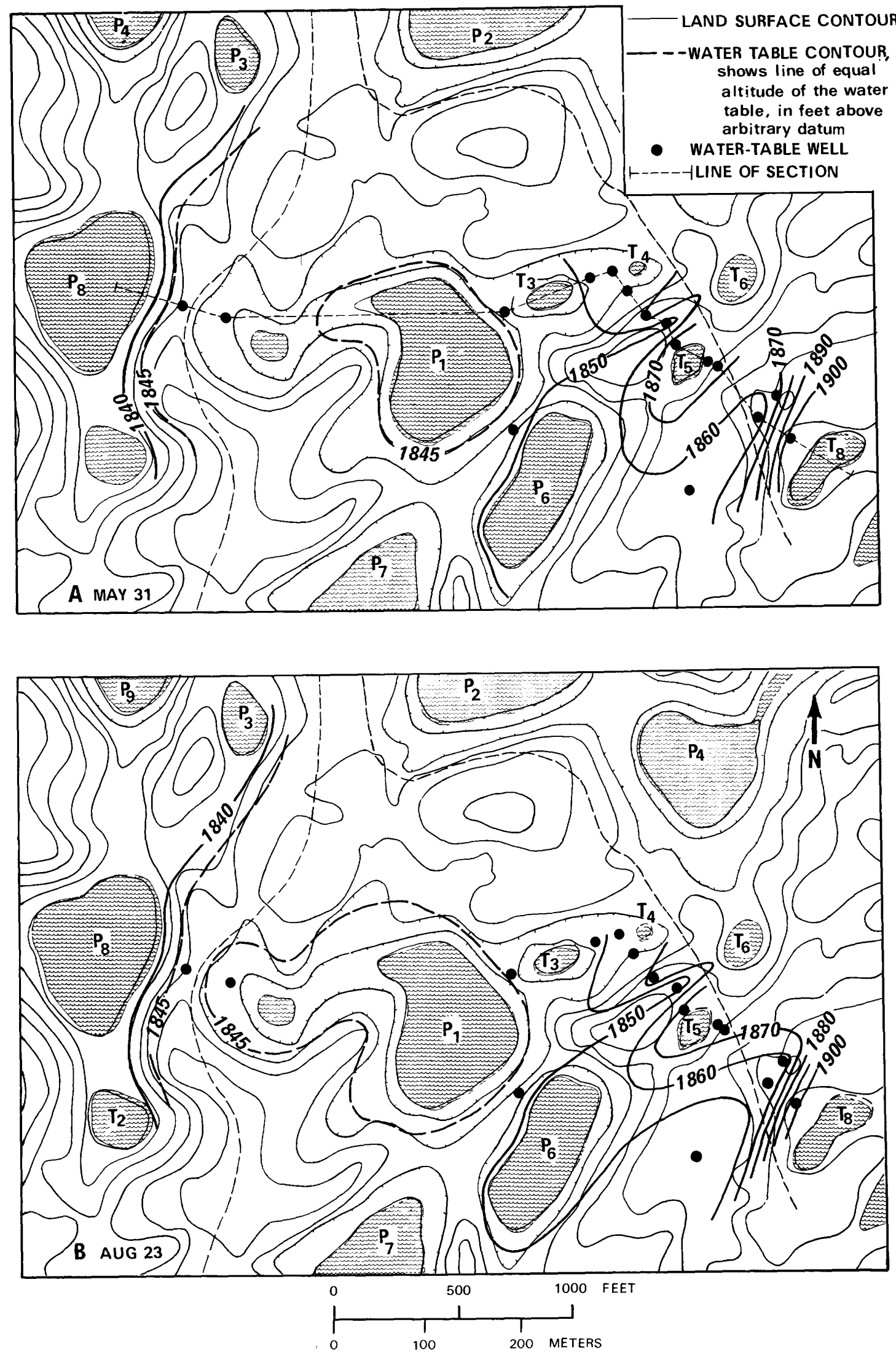

Figure 16.--Water-table maps of part of the study site. (A) May 31, 1979. (B) August 23, 1979. 


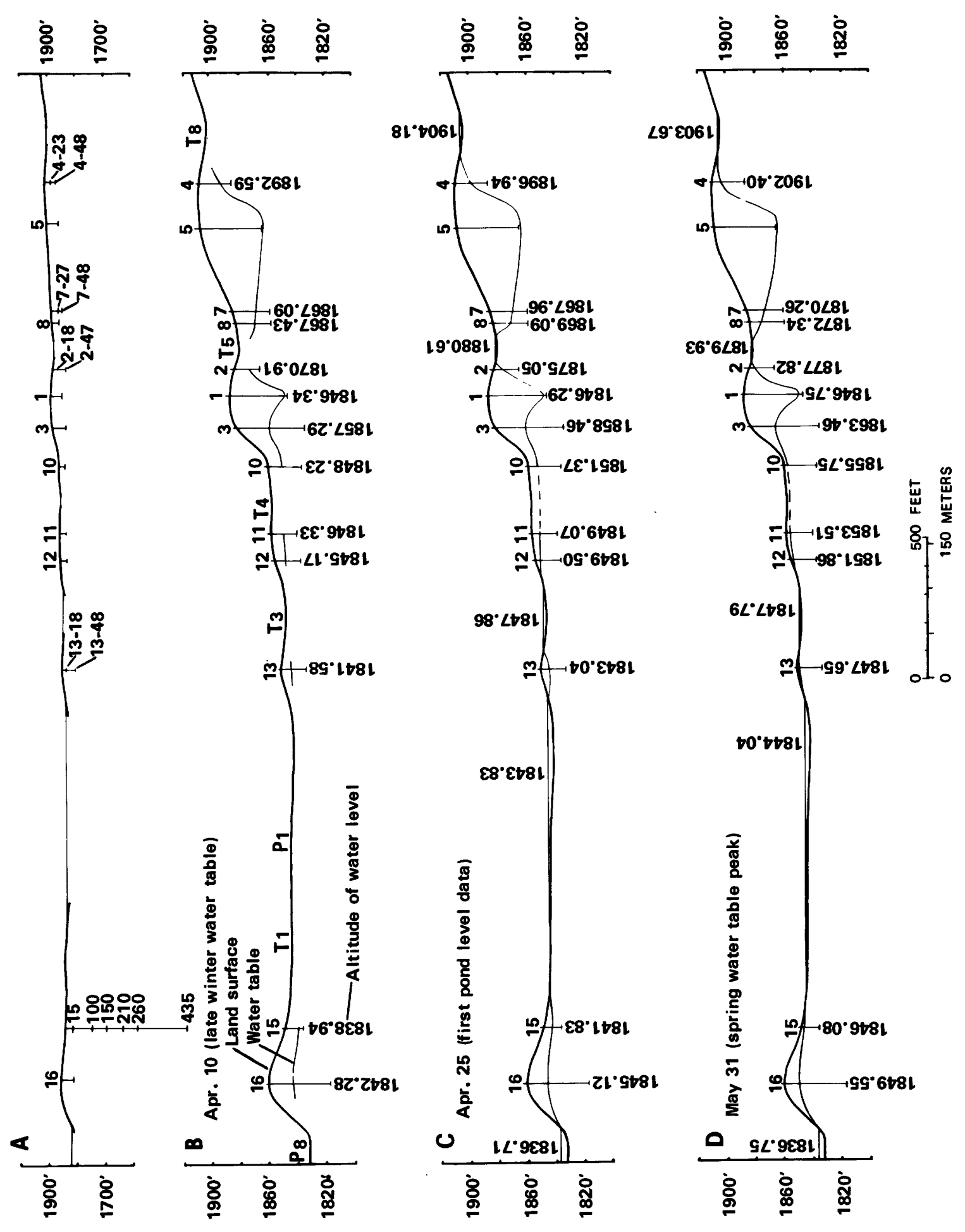



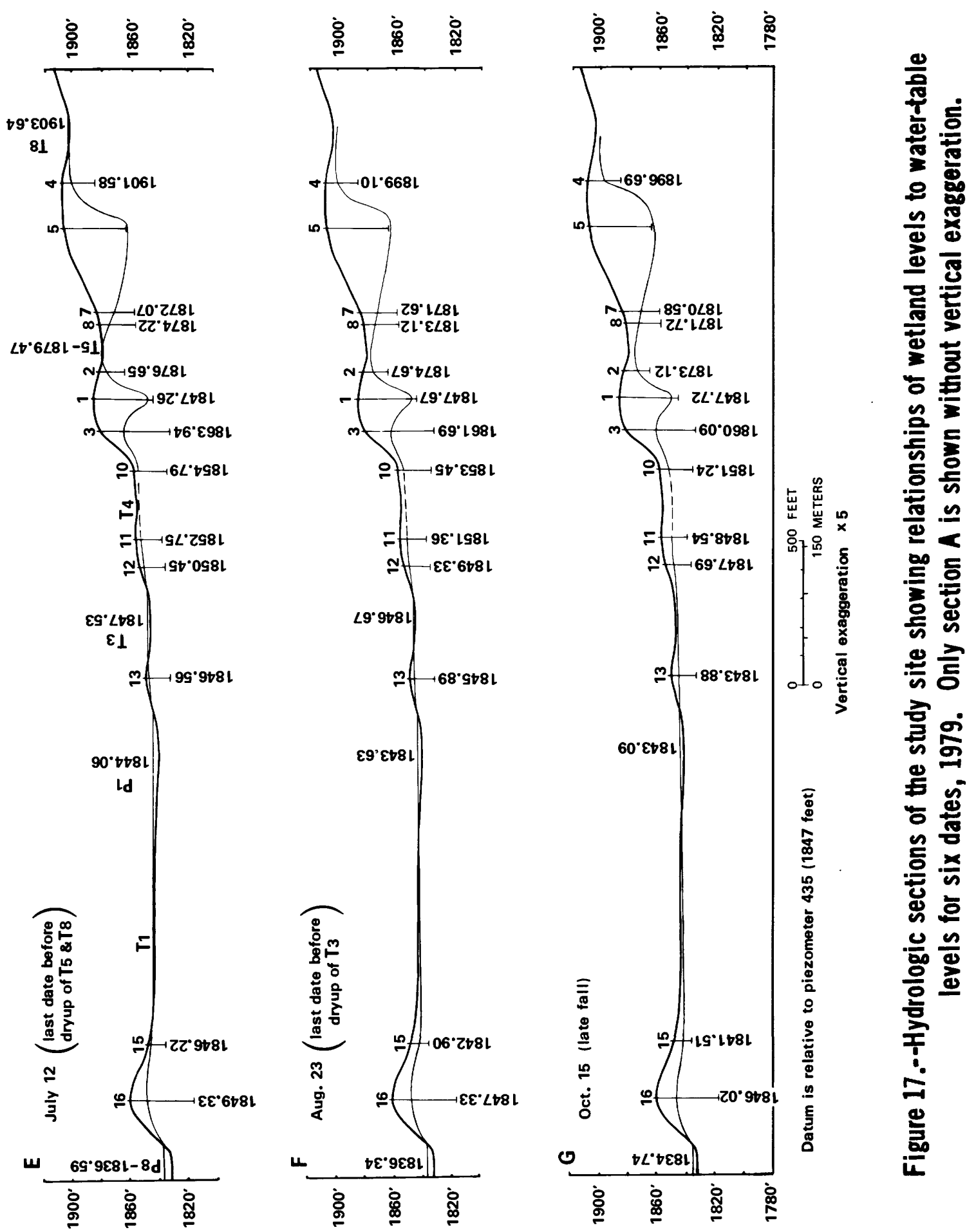
indicating the ground-water system responds slowly in the areas between some of the wetlands. It appears that in the higher parts of the area, where the water table is relatively deep, water-table highs do not underlie landsurface highs. In these areas the water-table mounds are created by seepage from wetlands--the ground-water system then slowly fills in beneath the interwetland topographic highs.

Below the steep slope between wells 10 and 1 , the interaction of ground water and wetlands appears to differ from the higher area just discussed. The water table always slopes toward wetland T3 on the upgradient side (see wells 11 and 12), indicating ground-water seepage to wetland T3. Watertable levels on the downgradient side of T3 are always lower than the wetland level, indicating seepage from wetland T3 to the ground-water system. The water table in this small inter-wetland area comes very close to pond levels during the spring water-table high (fig. 17D). Thus wetland T3, and probably T4 are flow-through type wetlands.

For a time during late winter and early spring, wetland $\mathrm{P} 1$ has seepage from it on its upgradient side, the side toward wetland T3 (fig. 17C). This appears to be a late winter condition only because as late as mid-0ctober (fig. 17G) the water-table gradient is toward P1 even after T3 dries up.

On the downgradient side of wetland P1 the water-table has a mound higher than $\mathrm{P} 1$ at al1 times, as indicated by water levels in well 16 . Waterlevel information from wel1 15, closer to the wetland than well 16 , shows a water table lower than in $\mathrm{Pl}$ prior to spring recharge (fig. 17C), but a higher water table related to spring recharge persists into July (fig. $17 \mathrm{E}$ ). By late August (fig. 17F), however, the water level in well 15 is lower than in wetland P1. This information indicates that wetlands in the lowest parts of the study area, possibly $\mathrm{P} 1$ and probably $\mathrm{P} 8$, are ground-water discharge areas most, if not a11, of the time.

The importance of a water-table mound on the downgradient side of lakes and wetlands as a factor in controlling seepage from then is discussed by Winter $(1976,1978 \mathrm{~b})$. The information provided by those studies was the basis for locating the nest of piezometers on the downgradient side of wetland $\mathrm{P} 1$, near well 15 . Information on hydraulic head at various depths at this site was not available for this report. The relatively small hydraulic conductivity of the glacial till results in very long lag times in piezometer response, therefore it will be necessary to place packers and pressure transducers in the piezometers in order to increase their sensitivity and obtain reliable hydraulic-head data.

The preceding discussion on local conditions at the study site is based on data only for 1979. The interrelationship of wetlands and ground water undoubtedly varies from year to year. Numerical simulation of transient conditions at the study site, planned for subsequent phases of the project, will be useful not only for detailed analysis of specific questions, such as the dynamic shape of the water-table depression under the land surface highs in the higher parts of the area, but also for assessing the effect on ground water and wetlands of a number of climatic and man-made perturbations. 


\section{FUTURE STUDY NEEDS}

\section{Short Term}

The study site needs to be more fully instrumented in order to meet all the goals of the project. Concerning atmospheric water interchange with the wetlands, it would be useful to have a few local observers read rain gages near the study site. One of the goals of the project is to assess alternative study approaches so choices can be made for other studies. For example at Williams Lake, Minnesota (Siegel and Winter, 1980), it was found that rainfall data from nearby observers were more accurate than that from National Weather Service stations located a long distance from the site of interest. A similar study needs to be conducted for the prairie environment.

The present type and position of instruments for measuring evaporation from wetland P1 is based on experience on large western reservoirs. Considering the size of prairie wetlands and the fact that they are intermittently covered with vegetation, some of the basic assumptions made for evaporation studies of large western reservoirs might not apply to estimating evaporation from small wetlands. Additional anemometers and humidity sensors need to be placed on wetland P1 as soon as possible so an understanding of wind and water vapor profiles over the wetland can be attained.

More water-table wells are needed at the study site to better define the areal configuration of the water table than is presently possible (fig. 16). Also, recent theoretical modeling studies indicate a few additional wells are needed along the profile already existing. If the study area should be extended to include wetlands T2, P8, and P9, a few surface-water streamflow gages will be necessary.

The need for information on the anisotropy of the glacial deposits is amply demonstrated in this report. Methods need to be devised to obtain this critical parameter.

\section{Long Term}

To obtain the best estimate of evaporation and to calibrate the best mass-transfer coefficient, it will be necessary to instrument the site for energy-budget studies for at least 2 years.

For thorough understanding of the response of the ground-water system and adjacent wetlands to short- and long-term climatic events, detailed studies of water movement in the unsaturated zone will be necessary at a few selected sites. This is the only way that growth and dissipation of water-table mounds, a key control on wetland seepage, will be thoroughly understood.

The study site is located in a regional topographic high, an area generally considered to be a regional ground-water recharge area. For 
more thorough understanding of wetland hydrology on a regional scale it would be desirable to establish a study site similar to the present one in a regional topographic low. If a site was established in the lowland to the west of the present site, for example, the interaction of lakes and wetlands with ground-water flow systems of several magnitudes could be studied.

\section{REFERENCES}

Allred, E. R., Manson, P. W., Schwartz, G. M., Golany, P., and Reinke, J. W. , 1971, Continuation of studies on the hydrology of ponds and small lakes: University of Minnesota, Agricultural Experiment Station, Technical Bulletin 274, 62 p.

Barari, Assad, 1971a, Hydrology of Lake Kampeska: South Dakota Geological Survey Report of Investigations 103, 84 p.

1971b, Hydrology of Lake Poinsett: South Dakota Geological Survey Report of Investigations $102,69 \mathrm{p}$.

Bluemle, J. P., 1971, Depth to bedrock in North Dakota: North Dakota Geologica1 Survey, Miscellaneous Map 13.

Carlson, C. G., 1969, Bedrock geologic map of North Dakota: North Dakota Geological Survey, Miscellaneous Map 10.

Colton, R. B., Lemke, R. W., and Lindva11, R. M., 1963, Preliminary glacial map of North Dakota: U.S. Geological Survey Miscellaneous Investigations Map I-331.

Downey, J. A., and Peterka, J. J., 1978, Relationship of rainfall and lake groundwater seepage: Limnology and Oceanography, v. 23, no. 4, p. 821-825.

Eisenlohr, W. S., and others, 1972, Hydrologic investigations of prairie potholes in North Dakota, 1959-68: U.S. Geological Survey Professiona1 Paper 585-A, 102 p.

Freeze, R. A., 1969, Theoretical analysis of regional groundwater flow: Canadian Department of Energy, Mines, and Resources, Inland Waters Branch, Scientific Series 3, 147 p.

Harbeck, G. E., Jr., 1962, A practical field technique for measuring reservoir evaporation utilizing mass-transfer theory: U.S. Geological Survey Professiona1 Paper 272-E, p. 101-105.

Huxel, C. J., Jr., and Petri, L. R., 1963, Geology and ground-water resources of Stutsman County, North Dakota--Part II, Ground water basic data: North Dakota Geological Survey Bulletin 41, North Dakota State Water Conservation Commission County Ground Water Studies 2, 339 p. 
Jensen, R. E., no date, Climate of North Dakota: Fargo, North Dakota State University, $48 \mathrm{p}$.

Kohler, M. A., Nordenson, T. J., and Baker, D. R., 1959, Evaporation maps for the United States: U.S. Weather Bureau Technical Paper 37, 13 p.

Lissey, A., 1971, Depression-focused transient groundwater flow patterns in Manitoba: The Geological Association of Canada, Special Paper no. 9, p. 333-341.

Maclay, R. W., Winter, T. C., and Bidwe11, L. E., 1972, Water resources of the Red River of the north drainage basin in Minnesota: U.S. Geological Survey Water Resources Investigations WRI 1-72, 129 p.

Meyboom, P., 1963, Patterns of ground-water flow in the prairie profile: p. 5-20 in proceedings of Hydrology Symposium no. 3, Ground Water: Ottawa, Queen's Printer, 394 p.

1966, Unsteady groundwater flow near a willow ring in hummocky moraine: Journal of Hydrology, v. 4, p. 38-62.

1967, Mass-transfer studies to determine the ground-water regime of permanent lakes in hummocky moraine of western Canada: Journal of Hydrology, v. 5, p. 117-142.

Patterson, D. D., Johnsgard, G. A., Sweeney, M. D., and Omodt, H. W., 1968, Soil Survey Report, County General Soil Maps, North Dakota: North Dakota State University, Agricultural Experiment Station Bulletin 473, $150 \mathrm{p}$.

Randich, P. G., Petri, L. R., and Adolphson, D. G., 1962, Geology and groundwater resources of Kidder County, North Dakota--Part II, Ground-water basic data: North Dakota Geological Survey Bulletin 36, North Dakota State Water Conservation Commission County Ground Water Studies 1, 134 p.

Shjef1o, J. B., 1968, Evapotranspiration and the water budget of prairie potholes in North Dakota: U.S. Geological Survey Professional Paper 585-B, $49 \mathrm{p}$.

Siege1, D. I., and Winter, T. C., 1980, Hydrologic setting of Williams Lake, Hubbard County, Minnesota: U.S. Geological Survey Open-File 80-403, 56 p.

Sloan, C. E., 1972, Ground-water hydrology of prairie potholes in North Dakota: U.S. Geological Survey Professional Paper 585-C, 28 p.

Stewart, R. E., and Kantrud, H. A., 1972, Vegetation of prairie potholes, North Dakota, in relation to quality of water and other environmental factors: U.S. Geological Survey Professional Paper 585-D, 36 p. 
Van Voast, W. A., and Novitzki, R. P., 1968, Ground-water flow related to streamflow and water quality: Water Resources Research, v. 4, no. 4, p. 769-775.

Winter, T. C., 1976, Numerical simulation analysis of the interaction of lakes and ground water: U.S. Geological Survey Professional Paper 1001, $45 \mathrm{p}$.

1978a, Ground-water component of lake water and nutrient budgets:

Verhandlungen Internationale Vereinigung Limnologie, v. 20, p. 438-444.

1978b, Numerical simulation of steady-state three-dimensional groundwater flow near lakes: Water Resources Research, v. 14, no. 2, p. 245254.

1981, Uncertainties in estimating the water balance of lakes: Water Resources Bulletin, v. 17, [in press]. 